\title{
Critical Assessment of the Al-Ti-Zr System
}

\author{
Z. Kahrobaee ${ }^{1} \cdot$ M. Palm ${ }^{1}$
}

Submitted: 28 July 2020/ Accepted: 8 September 2020/Published online: 14 October 2020

(C) The Author(s) 2020

\begin{abstract}
Only within the last couple of years, complete isothermal sections for the Al-Ti-Zr system have been determined. Up to then there had been several investigations, but these were limited to the $\mathrm{Ti}-\mathrm{Zr}$ and $\mathrm{Ti}-\mathrm{Al}$ sides and the $\mathrm{Ti}-$ and $\mathrm{Al}$ corners of the system. Also recently the system has been evaluated by thermodynamic ab initio calculations and CALPHAD-type (CALculation of PHAse Diagrams) modelling. As Al-Ti-Zr alloys are of interest for a variety of applications and as the last assessment has been performed more than 15 years ago, this new critical evaluation of the existing literature about phase equilibria in the Al-Ti-Zr system has been performed.
\end{abstract}

Keywords assessment · crystal structures · modelling · phase equilibria

\section{Introduction}

In view of applications, different parts of the Al-Ti-Zr system are of interest and investigation of phase equilibria over the decades reflects these interests. With the development of Ti-base alloys, the extension of the homogeneity ranges of $\beta(\mathrm{Ti}, \mathrm{Zr})$ and $\alpha(\mathrm{Ti}, \mathrm{Zr})$ within the ternary system in dependence of temperature have been investigated. ${ }^{[1-3]}$ In the $\mathrm{Al}$ corner of the system precipitation of $(\mathrm{Ti}, \mathrm{Zr}) \mathrm{Al}_{3}$ has

Z. Kahrobaee

z.kahrobaee@mpie.de

M. Palm

palm@mpie.de

1 Max-Planck-Institut für Eisenforschung GmbH, Düsseldorf, Germany been investigated for strengthening $\mathrm{Al}$ alloys at higher temperatures ${ }^{[4-7]}$ and for grain refining. ${ }^{[8-10]}$ As ductility may improve if instead of tetragonal $\mathrm{TiAl}_{3}\left(\mathrm{DO}_{22}\right)$ or $\mathrm{ZrAl}_{3}$ $\left(\mathrm{DO}_{23}\right)$ metastable (Ti,Zr) $\mathrm{Al}_{3}$ with cubic $\mathrm{Ll}_{2}$ structure forms, quite some effort has been spent on establishing phase stability in the Al-rich part of the system. ${ }^{[11-17]}$ With the industrialisation of $\gamma$ TiAl based alloys, phase equilibria among the Ti-Al based phases in this system came into focus. ${ }^{[18-23]}$ While all these activities were limited to specific parts of the system, studies of full isothermal sections have been performed only very recently. ${ }^{[24,25]}$

Though of some practical importance, experimental difficulties in investigating $\mathrm{Ti}-\mathrm{Al}(-\mathrm{X})$ systems at high temperatures make the determination of phase equilibria difficult. High susceptibility to impurities, specifically oxygen, which can have a pronounced effect on phase equilibria, reactions of melts with crucibles or preferential evaporation of $\mathrm{Al}$ are some of these problems. ${ }^{[26,27]}$ The addition of $\mathrm{Zr}$ does not improve things, as it is also highly susceptible to oxygen uptake and because of its high melting point and low diffusivity, quite long annealing times are necessary to attain equilibrium even at high temperatures. ${ }^{[24,25]}$ And the fact that even "high-purity" $\mathrm{Zr}$ contains comparable high amounts of impurities, ${ }^{[18,28]}$ specifically Hf, is most of the time neglected.

The key for any aimed alloy development is a sound knowledge of phase equilibria in dependence of temperature and composition. In this regard, assessments play an important role as they collect all the available evidence and critically evaluate it. This is specifically true for the $\mathrm{Al}-\mathrm{Ti}-\mathrm{Zr}$ system, where until recently only scattered information had been available. The current work continues previous assessments by Ansara et al. ${ }^{[29]}$ and Tretyachenko, ${ }^{[30]}$ which have been performed in the framework of MSIT, the Materials Science International Team. The 
activities of MSIT are inextricably associated with Günter Effenberg and his awareness of the importance of phase diagrams, thermodynamic and crystallographic data. This assessment is dedicated in memory of him.

\section{Binary Systems}

The binary Al-Zr system is accepted from (Ref 31). The different assessments of the $\mathrm{Al}-\mathrm{Zr}$ system ${ }^{[31-33]}$ and the thermodynamic modelling ${ }^{[34-36]}$ are in good agreement with each other. According to them, ten stable intermetallic phases, all with restricted homogeneity ranges, exist: $\mathrm{Zr}_{3} \mathrm{Al}, \mathrm{Zr}_{2} \mathrm{Al}, \mathrm{Zr}_{5} \mathrm{Al}_{3}, \mathrm{Zr}_{3} \mathrm{Al}_{2}, \mathrm{Zr}_{4} \mathrm{Al}_{3}, \mathrm{Zr}_{5} \mathrm{Al}_{4}, \mathrm{ZrAl}, \mathrm{Zr}_{2} \mathrm{Al}_{3}$, $\mathrm{ZrAl}_{2}$, and $\mathrm{ZrAl}_{3}$. Their crystallographic structures, lattice parameters and stability ranges are listed in Table 1 . For $\mathrm{ZrAl}_{3}$ it has been shown more recently that the phase forms by the peritectic reaction $\mathrm{L}+\mathrm{ZrAl}_{2} \leftrightarrow \mathrm{ZrAl}_{3}{ }^{[37]}$ in agreement with a previous modelling, ${ }^{[32]}$ rather than being a congruent melting compound. ${ }^{[31,33]}$ The lower stability of the phases $\mathrm{Zr}_{5} \mathrm{Al}_{3}$ and $\mathrm{Zr}_{5} \mathrm{Al}_{4}$ and the upper stability of $\mathrm{Zr}_{3} \mathrm{Al}_{2}$ are uncertain. ${ }^{[31]}$ Also the liquidus and solidus of $\beta(\mathrm{Zr})$ have not been precisely determined, while the $\beta(\mathrm{Zr}) / \beta(\mathrm{Zr})+\mathrm{Zr}_{3} \mathrm{Al}$ and $\beta(\mathrm{Zr}) / \beta(\mathrm{Zr})+\alpha(\mathrm{Zr})$ phase boundaries were determined in (Ref 38). The Ti-Zr system, which is accepted from Malfliet et al. (Ref 39), shows complete miscibility in the liquid and in the solid. The TiAl system has been assessed more recently in (Ref 27,40,41). Here the version by (Ref 27) is accepted, as it seems to be the most comprehensive evaluation of experimental data. While no substantial new experimental results have become available since then, modelling may yield some insight in two existing controversies about phase equilibria in the Ti-Al system. ${ }^{[42]}$ The first one regards the possible B2 ordering in $\beta(\mathrm{Ti})$. Wang et al. (Ref 43) combined ab initio calculations with CALPHAD modelling and showed that in the "pure" Ti-Al system no B2 ordering is observed. However, if substitutional vacancies and anti-site defects are taken into account in B2, then ordered $\beta(\mathrm{Ti})$ is observed, thereby stabilising $\beta(\mathrm{Ti})$ at higher $\mathrm{Al}$ contents. As a consequence, B2-ordered $\beta(\mathrm{Ti})$ forms an equilibrium with $\alpha_{2} \mathrm{Ti}_{3} \mathrm{Al}$, whereby the homogeneity range of $\alpha(\mathrm{Ti})$ gets interrupted by the two invariant reactions $\beta(\mathrm{Ti})+\alpha(\mathrm{Ti}) \leftrightarrow \mathrm{Ti}_{3} \mathrm{Al}$ at about $1200 \pm 10{ }^{\circ} \mathrm{C}$ and $\beta(\mathrm{Ti})+\mathrm{Ti}_{3} \mathrm{Al} \leftrightarrow \alpha(\mathrm{Ti})$ at $1170 \pm 10{ }^{\circ} \mathrm{C} \cdot{ }^{[43]}$ As substitutional vacancies and anti-site defects have to be expected at the respective temperatures, it now becomes clear why, in contrast to experimental evidence, modelling of the "pure" Ti-Al system shows a continuous $\alpha(\mathrm{Ti})$ phase field. ${ }^{[43-48]}$ Another open question is the transition from high-temperature $\mathrm{TiAl}_{3} \quad\left(\mathrm{DO}_{22}\right)$ to the low-temperature $\mathrm{D0}_{23}$-polymorph. ${ }^{[27]}$ Recent density functional theory (DFT) calculations by Fang and Fan (Ref 49) showed that a series of intermediate stacking configurations of high stability exist. As even annealing for long time at intermediate temperatures may not equilibrate these "wrong" stacking, it becomes clear why $\mathrm{TiAl}_{3}$ compounds of varying stacking sequences have been observed in dependence on individual experimental conditions. ${ }^{[50]}$ Therefore also the recent update of the system ${ }^{[42]}$ shows only the presence of the two polymorphs $\mathrm{TiAl}_{3}(\mathrm{~h})$ and $\mathrm{TiAl}_{3}(\mathrm{l})$, but no transformation temperature.

\section{Phases}

Some of the binary phases show large solid solubility ranges for the third element and two ternary compounds, $\mathrm{Ti}_{2} \mathrm{AlZr}^{[51-53]}$ and $\mathrm{Zr}_{2} \mathrm{TiAl}^{[54]}$ have been reported which actually could be ordered structures within the wide homogeneity range of $\beta(\mathrm{Ti}, \mathrm{Zr})$.

Addition of $\mathrm{Zr}$ to $\mathrm{Ti}$ or $\mathrm{Ti}$ to $\mathrm{Zr}$ stabilizes $\beta$ with respect to $\alpha$, i.e. in both cases the $\alpha / \beta$ transformation temperature is lowered. ${ }^{[55,56]}$ Within the Al-Ti-Zr system $\beta(\mathrm{Ti}, \mathrm{Zr})$ encompasses a wide range of compositions. At high temperatures it includes the stoichiometric compositions $\mathrm{Ti}_{2} \mathrm{AlZr}$ and $\mathrm{Zr}_{2} \mathrm{TiAl}$, for which both specific crystallographic structures have been reported (Table 1).

Al-rich samples of $\beta(\mathrm{Ti}, \mathrm{Zr})$ annealed for $168 \mathrm{~h}$ at $900{ }^{\circ} \mathrm{C}$ showed B2-ordering. ${ }^{[57]} \mathrm{In}$ an as-cast alloy of stoichiometric composition, the two phases $\mathrm{Ti}_{2} \mathrm{AlZr}$ and $\mathrm{Zr}_{5} \mathrm{Al}_{3}$ were observed. ${ }^{[52]}$ In the as-cast condition $\mathrm{Ti}_{2} \mathrm{AlZr}$ showed the $\mathrm{D}_{19}$ structure, space group $\mathrm{P}_{3} / m m c$, while after annealing at $1200{ }^{\circ} \mathrm{C}$ for $30 \mathrm{~min}$ and also after subsequent ageing at $500{ }^{\circ} \mathrm{C}$ for $100 \mathrm{~h}$ or at $700{ }^{\circ} \mathrm{C}$ for $24 \mathrm{~h}$ single-phase $\mathrm{B} 2$-ordered $\beta(\mathrm{Ti}, \mathrm{Zr})$ was obtained. ${ }^{[52]}$ Mechanical deformation lead to the formation of orthorhombic martensite. ${ }^{[52,58]}$ B2 ordering was also reported for Al-rich $\beta(\mathrm{Ti}, \mathrm{Zr})$ synthesised from hydrides at $1000{ }^{\circ} \mathrm{C} .{ }^{[59]}$ Contrary to these observations, $\mathrm{Ti}_{2} \mathrm{AlZr}$ with D0 19 structure was also observed after annealing an arcmelted button of the stoichiometric composition at $1000{ }^{\circ} \mathrm{C}$ for $720 \mathrm{~h}^{\left[{ }^{[51]}\right.}$ This is in agreement with ab initio calculations, which predicted that $\mathrm{Ti}_{2} \mathrm{AlZr}$ will have the $\mathrm{D} 0_{19}$ structure. ${ }^{[53,60,61]}$ However, quenching or deformation of Ti-rich compositions of $\beta(\mathrm{Ti}, \mathrm{Zr})$ may lead to formation the hexagonal $\omega$ phase and orthorhombic $\alpha^{\prime \prime}$ and hexagonal $\alpha^{\prime}$ martensite ${ }^{[52,53,56,58]}$ like in many other Ti-based alloys, e.g. in the Ti-Al-Nb system. However, details how the formation of the individual crystallographic structures depends on composition and quenching conditions still have to be established. The site occupation within the B2-ordered phase has been modelled by ab initio calculations. ${ }^{[62]}$ Interdiffusion coefficients for Ti-rich $\beta(\mathrm{Ti}, \mathrm{Zr})$ at $1000{ }^{\circ} \mathrm{C}$ and $1200{ }^{\circ} \mathrm{C}$ have been determined in (Ref 63). 


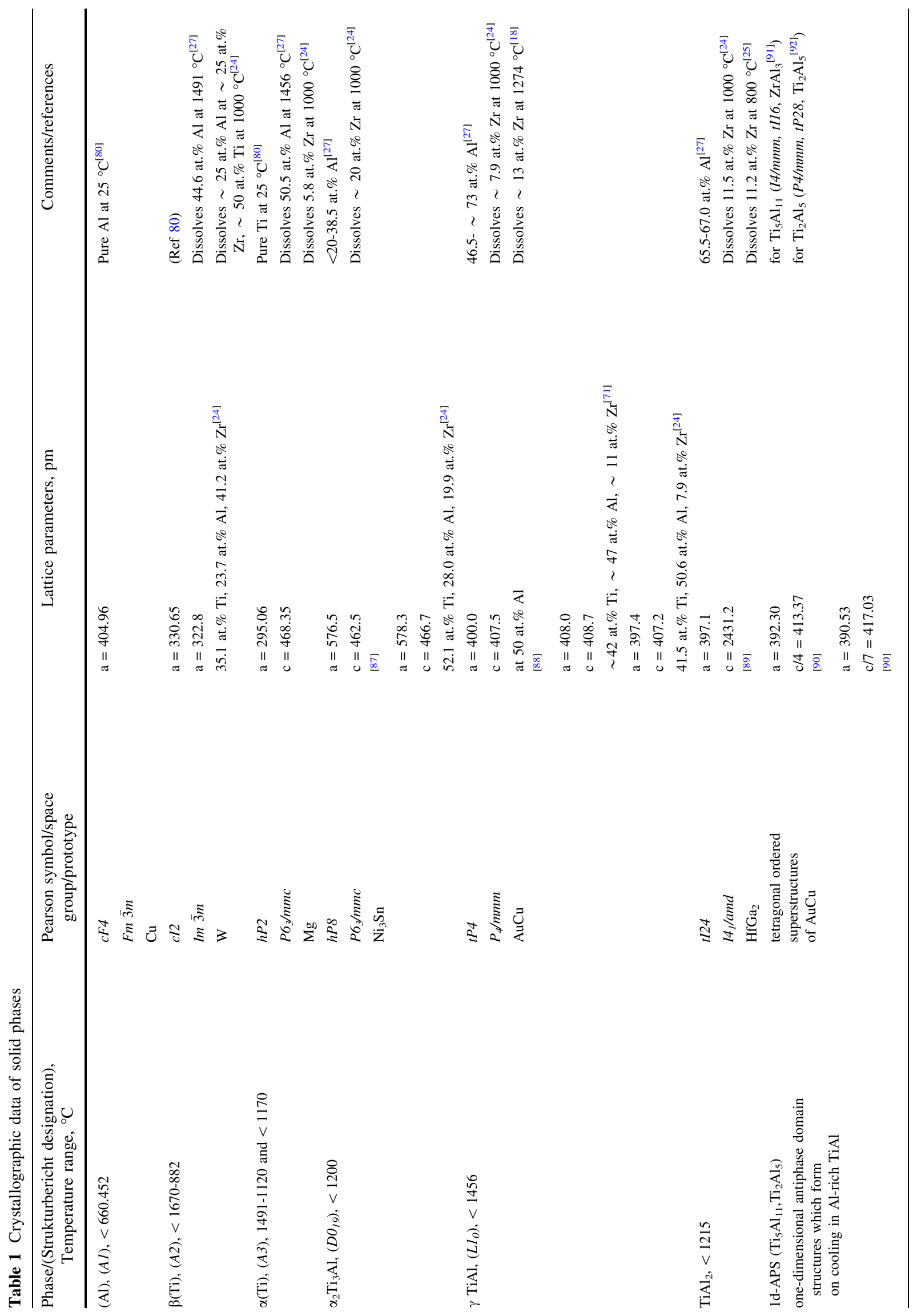




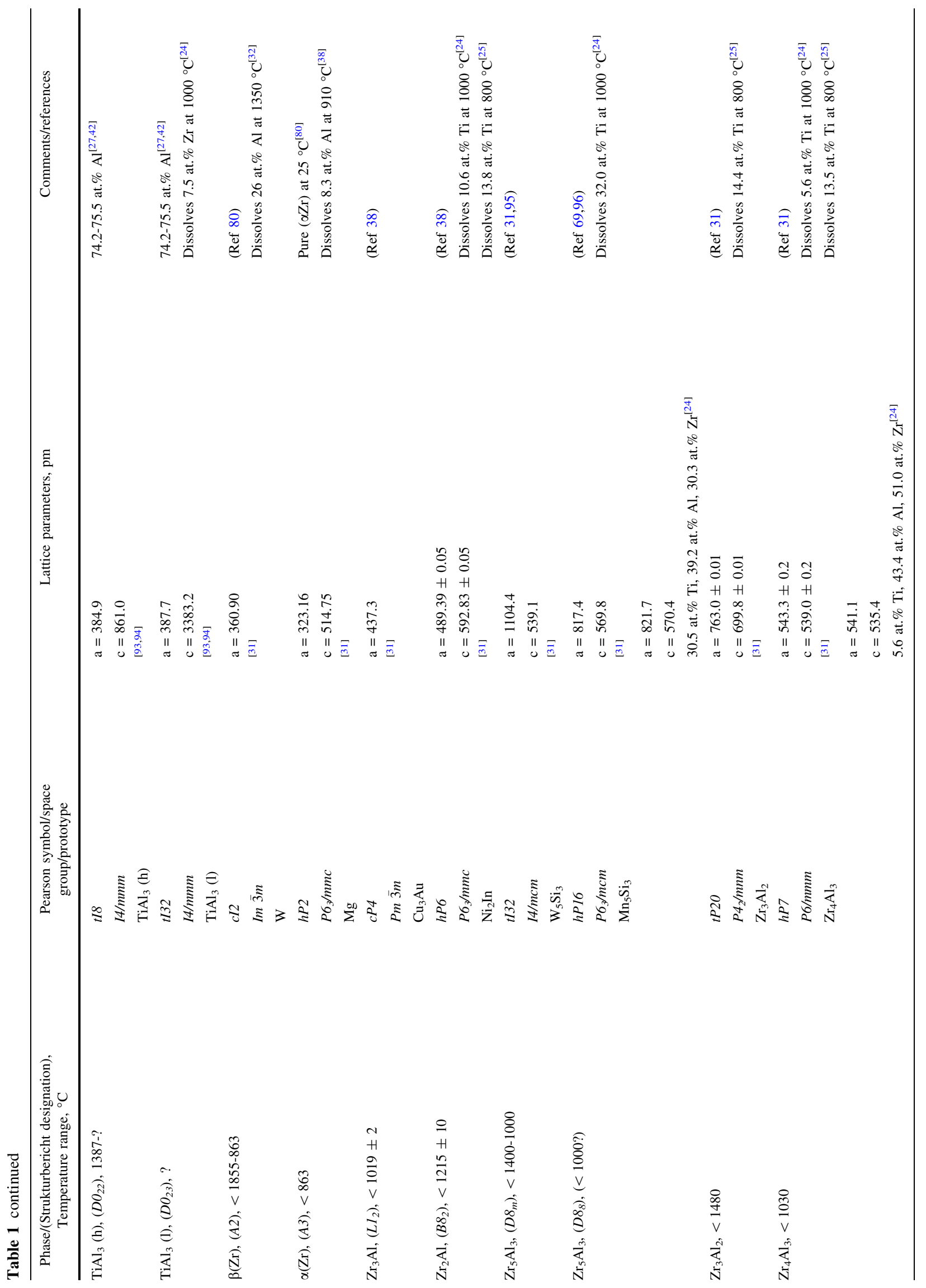




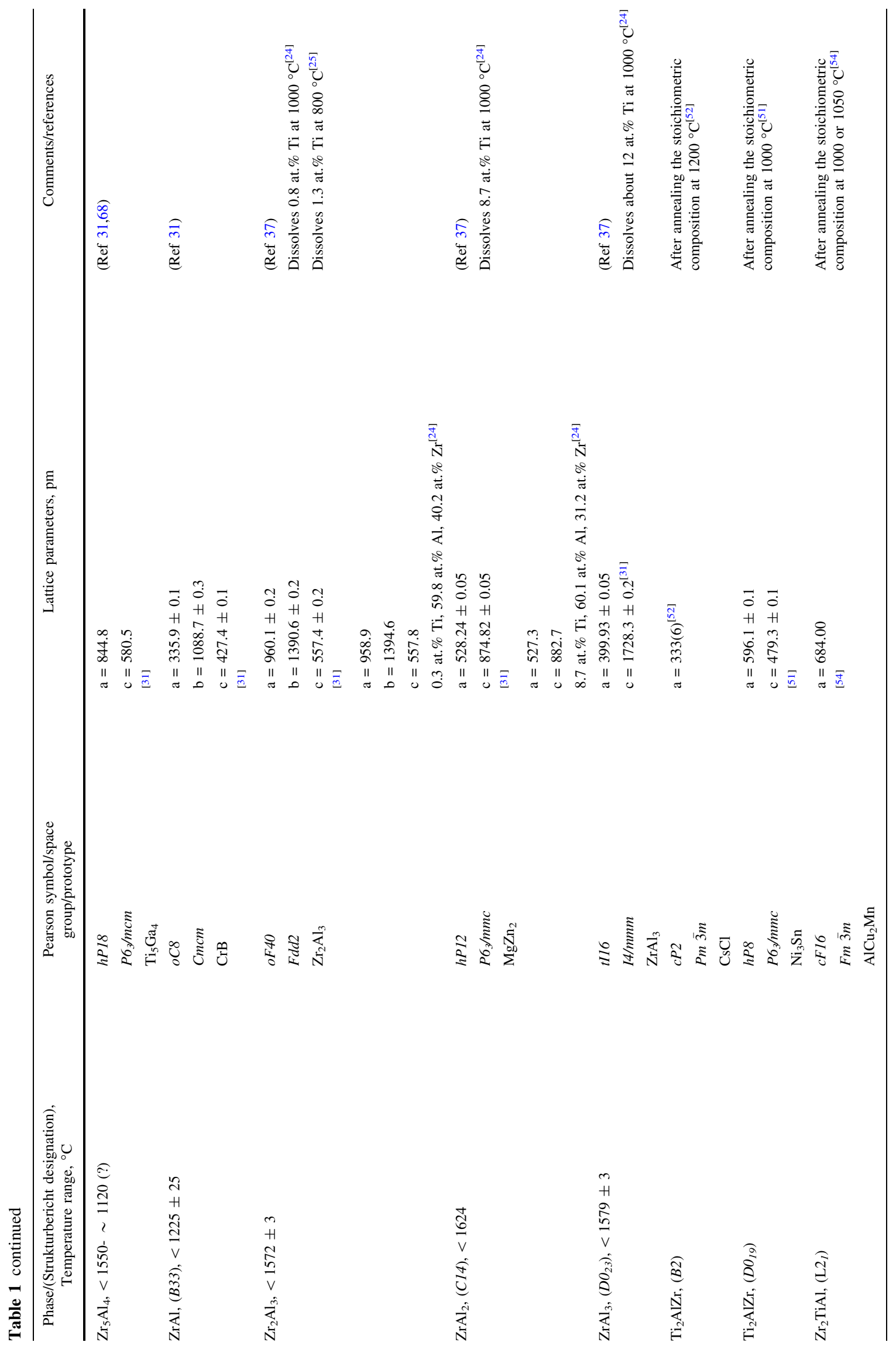


A phase $\mathrm{Zr}_{2} \mathrm{AlTi}$ with cubic L2 $2_{1}$ structure, space group $F m \overline{3} m$ was found in an alloy of stoichiometric composition after annealing at $1050{ }^{\circ} \mathrm{C}$ for $720 \mathrm{~h}$ or $1000{ }^{\circ} \mathrm{C}$ for 480 h. ${ }^{[54]}$ The analysed composition of $\mathrm{Zr}_{2} \mathrm{AlTi}$ lies near or at the $\beta(\mathrm{Ti}, \mathrm{Zr}) / \beta(\mathrm{Ti}, \mathrm{Zr})+(\mathrm{Zr}, \mathrm{Ti})_{5} \mathrm{Al}_{3}$ phase boundary. ${ }^{[24,64]}$ That $\mathrm{Zr}_{2}$ AlTi was accompanied by two other phases, of which one could be $(\mathrm{Zr}, \mathrm{Ti})_{5} \mathrm{Al}_{3}$ or $(\mathrm{Zr}, \mathrm{Ti})_{2} \mathrm{Al}$ according to X-ray diffraction (XRD) and analysed composition, ${ }^{[54]}$ may indicate that also this structure may result from ordering within $\beta(\mathrm{Ti}, \mathrm{Zr})$.

All phases originating in the binary Ti-Al system show a marked solid solubility for $\mathrm{Zr}$ (Table 1). At $1000{ }^{\circ} \mathrm{C} 6$ at.\% $\mathrm{Zr}$ in $\alpha(\mathrm{Ti}, \mathrm{Zr}), 20$ at.\% $\mathrm{Zr}$ in $\mathrm{Ti}_{3} \mathrm{Al}, 8$ at.\% $\mathrm{Zr}$ in $\mathrm{TiAl}, 12$ at. $\% \mathrm{Zr}$ in $\mathrm{TiAl}_{2}$ and 7.5 at. $\% \mathrm{Zr}$ in $\mathrm{TiAl}_{3}$ may dissolve. ${ }^{\text {[24] }}$ The solid solubility in all phases seems to increase with increasing temperature, e.g. at $1274{ }^{\circ} \mathrm{C}$ about 13 at.\% $\mathrm{Zr}$ may dissolve in TiAl. ${ }^{[18]}$ For the site occupation of $\mathrm{Zr}$ in TiAl a strong preference for $\mathrm{Ti}$ sites was found. ${ }^{[18,20-22,65,66]}$ Also in $\mathrm{Ti}_{3} \mathrm{Al} \mathrm{Zr}$ substitutes for Ti. ${ }^{[22,65,66]}$ It was also found that the temperature of the $\alpha(\mathrm{Ti}, \mathrm{Zr}) / \mathrm{Ti}_{3} \mathrm{Al}$ phase boundary is only slightly raised by the addition of $\mathrm{Zr}$. $^{[3]}$

The change from $\mathrm{TiAl}_{3}$ with $\mathrm{DO}_{22}$-structure to $\mathrm{ZrAl}_{3}$ ( $\mathrm{DO}_{23}$-structure) along $(\mathrm{Ti}, \mathrm{Zr}) \mathrm{Al}_{3}$ in dependence of composition and temperature was investigated by high-temperature XRD. ${ }^{[12]}$ Lattice constants for $(\mathrm{Ti}, \mathrm{Zr}) \mathrm{Al}_{3}$ with $\mathrm{D}_{22}$ - and $\mathrm{DO}_{23}$-structure have been determined in (Ref $4,6,12,59)$ and for metastable $\mathrm{L}_{2}$ in $(\operatorname{Ref} 7,11,13,15,16)$. The formation of metastable $(\mathrm{Ti}, \mathrm{Zr}) \mathrm{Al}_{3}$ with $\mathrm{L}_{1}{ }_{1}$-structure in $\mathrm{Al}$ has been investigated in (Ref 17) and transformation to stable $\mathrm{DO}_{23}$ during aging between 450 and $600{ }^{\circ} \mathrm{C}$ was studied by transmission electron microscopy (TEM). ${ }^{[14]}$

Also, most phases originating in the binary $\mathrm{Zr}-\mathrm{Al}$ system show a marked solid solubility for Ti (Table 1). Solid solubilities of about 12 at.\% $\mathrm{Ti}$ in $\mathrm{ZrAl}_{3}, 9$ at.\% $\mathrm{Ti}$ in $\mathrm{ZrAl}_{2}$, and even 32 at. $\% \mathrm{Ti}$ in $\mathrm{Zr}_{5} \mathrm{Al}_{3}$ at $1000{ }^{\circ} \mathrm{C}^{[24]}$ and about 14 at.\% Ti in $\mathrm{Zr}_{4} \mathrm{Al}_{3}, \mathrm{Zr}_{3} \mathrm{Al}_{2}$ and $\mathrm{Zr}_{2} \mathrm{Al}$ at $800{ }^{\circ} \mathrm{C}$ have been reported. ${ }^{[25]}$

\section{Isothermal Section at $1000{ }^{\circ} \mathrm{C}$}

Most data are available for $1000{ }^{\circ} \mathrm{C}$ and the most comprehensive investigation was performed by (Ref 24), who determined a complete isothermal section (Fig. 1). More than 38 alloys of about 5 grams each were produced by arcmelting. As the weight loss during alloy production did not exceed $1 \%$, nominal compositions have been considered as ultimate alloy compositions. Heat-treatments were performed at $1000{ }^{\circ} \mathrm{C}$ for $1440 \mathrm{~h}$ for samples encapsulated in quartz tubes back-filled with $\mathrm{Ar}$ followed by water quenching. Samples were examined by metallography,
XRD and electron probe microanalysis (EPMA). Compositions of coexisting phases were established by an average of five EPMA measurements. The standard deviations of the measured concentrations are \pm 0.6 at. $\%$ and the total mass of $\mathrm{Al}, \mathrm{Zr}$, and $\mathrm{Ti}$ was in the range of $97-103 \%$. Figure 1 shows the established isotherm from (Ref 24). While no ternary phases were detected, most binary phases show marked solid solubility ranges for the third component. It is noted that phase boundaries do not match those currently accepted for $\mathrm{Ti}^{-\mathrm{Al}^{[27]}}$ and that some phase boundaries are not in accordance with thermodynamic rules applying to isothermal sections. ${ }^{[67]}$ Extrapolation of the phase boundaries from the ternary system onto the binary Al-Zr system shows that apparently the "line compounds" $\mathrm{Zr}_{5} \mathrm{Al}_{3}$ and $\mathrm{ZrAl}_{2}$ have some marked solid solubility ranges in the binary. The phase $\mathrm{Zr}_{3} \mathrm{Al}$, which should be stable at $1000{ }^{\circ} \mathrm{C}$ (Table 1), has not been detected in (Ref 24). As the solid solubility for $\mathrm{Ti}$ in this phase could be very small, it may not have been observed, because no alloy of appropriate composition has been investigated. The phase $\mathrm{Zr}_{5} \mathrm{Al}_{4}$, which might be stable at $1000{ }^{\circ} \mathrm{C},{ }^{[31]}$ has also not been detected in (Ref 24). This is in line with an investigation of the $\mathrm{Fe}-\mathrm{Al}-\mathrm{Zr}$ system, which showed that this phase may only become stable above $\sim 1120{ }^{\circ} \mathrm{C} .{ }^{[68]}$ For a discussion, whether $\mathrm{Zr}_{5} \mathrm{Al}_{3}$ with the $\mathrm{Mn}_{5} \mathrm{Si}_{3}$-type crystal structure is stable in the binary Al-Zr system or not see (Ref 69). However, it is clear that impurities and third alloying elements stabilise the $\mathrm{Mn}_{5} \mathrm{Si}_{3}$-type structure in favour of $\mathrm{W}_{5} \mathrm{Si}_{3}$-type $\mathrm{Zr}_{5} \mathrm{Al}_{3}$, which might be the stable structure in binary $\mathrm{Al}-\mathrm{Zr}$ at $1000{ }^{\circ} \mathrm{C}$. ${ }^{[31]}$ Therefore, it is plausible that [24] observed the $\mathrm{Mn}_{5} \mathrm{Si}_{3}$-type structure for $(\mathrm{Zr}, \mathrm{Ti})_{5} \mathrm{Al}_{3}$. The phase $\mathrm{Ti}_{2} \mathrm{Al}_{5}$ has by now been identified as a one-dimensional antiphase domain structure, which forms from TiAl that becomes supersaturated in $\mathrm{Al}$ on cooling. ${ }^{\text {[27] }}$

Among other investigations at this temperature, the homogeneity range of TiAl was studied on 24 different arcmelted alloys, heat-treated at $1000{ }^{\circ} \mathrm{C}$ for $10 \mathrm{~h} .{ }^{[70]}$ Phases were identified by XRD but no compositions of coexisting phases were established. The solid solubility for $\mathrm{Zr}$ in TiAl was found to be about 15 at.\%, which is much higher than that reported in (Ref 24). Presumably-and as acknowledged by the authors-annealing times in (Ref 70) were too short for equilibrating TiAl. Therefore, alloys may have been supersaturated in $\mathrm{Zr}$ from the melting process at high temperatures and therefore the reported solid solubility may be too high. The solid solubility range of TiAl has also been examined on 21 alloys heat treated at $1000{ }^{\circ} \mathrm{C}$ for 168 h. ${ }^{[71]}$ Phases were analysed by XRD and compositions of phases were established by EPMA, but only lattice constants for TiAl are given and compositions can only be read for TiAl from a figure. According to this study the maximum solid solubility for $\mathrm{Zr}$ in $\mathrm{TiAl}$ could be about 11 at. $\%$ at about 47 at.\% Al. Also the presence of the three- 
phase equilibria $\mathrm{TiAl}+\mathrm{Ti}_{3} \mathrm{Al}+\mathrm{ZrAl}$ and $\mathrm{TiAl}+\mathrm{ZrAl}_{2}$ $+\mathrm{ZrAl}$ at $1000{ }^{\circ} \mathrm{C}$ is shown, ${ }^{[71]}$ in contradiction to the results by (Ref 24). The occurrence of phase equilibria between TiAl and $\mathrm{ZrAl}$ seems unlikely, because the solid solubility for $\mathrm{Ti}$ in $\mathrm{ZrAl}$ is very limited compared to that in $\mathrm{ZrAl}_{2}$ and $\mathrm{Zr}_{5} \mathrm{Al}_{3}$, which makes the presence of three-phase equilibria with the latter two phases more likely, as determined in (Ref 24) (Fig. 1 and 2). Two alloys investigated in (Ref 20) were single-phase TiAl after annealing at $1000{ }^{\circ} \mathrm{C}$ for $192 \mathrm{~h}$, in accordance with (Ref 24). The width of the $\mathrm{TiAl}+\mathrm{Ti}_{3} \mathrm{Al}$ two-phase field at $1000{ }^{\circ} \mathrm{C}$ was studied in (Ref 19) on 10 alloys, which were equilibrated for $168 \mathrm{~h}$. Phases were identified by XRD and for three alloys the compositions of the coexisting phases were established by EPMA. Compared to phase boundaries established in (Ref 24) and the current Ti-Al binary system, the results in (Ref 19) are somewhat shifted towards higher $\mathrm{Ti}$ contents by $2-3$ at.\%. The two-phase field was again studied in (Ref 23). Only one tie-line close to the Ti-Al binary system was established at $1000{ }^{\circ} \mathrm{C}$, which fits very well with the binary. ${ }^{[27]}$ The composition $50 \pm 2$ at.\% Ti, 25 at.\% $\mathrm{Zr}, 25 \pm 2$ at.\% $\mathrm{Al}$ was found to be single-phase $\mathrm{DO}_{19}$, the structure of $\mathrm{Ti}_{3} \mathrm{Al}$, after annealing at $1000{ }^{\circ} \mathrm{C}$ for $720 \mathrm{~h}^{[51]}$ Whether this means that $\mathrm{Ti}_{3} \mathrm{Al}$ may have a larger solid solubility for $\mathrm{Zr}$ than $\sim 20$ at.\%, as found in (Ref 24) or whether $\mathrm{D}_{19}$ forms on cooling at around $1000{ }^{\circ} \mathrm{C}$ from B2, as discussed before, cannot be settled based on the existing experimental evidence.

Vertical sections along Ti-14.9 at.\% Al/Zr, Ti-25.3 at.\% $\mathrm{Al} / \mathrm{Zr}$, and $\mathrm{Ti}-33.3$ at.\% $\mathrm{Al} / \mathrm{Zr}$ were investigated in the 1960 s by metallography, differential thermal analysis (DTA), and XRD and results were published in a series of overlapping papers. ${ }^{[5,64,72-75]}$ At $1000{ }^{\circ} \mathrm{C}$ samples were annealed for $100 \mathrm{~h}$ and quenched in water. All values for phase boundaries taken from the figures are unreasonable at $1000{ }^{\circ} \mathrm{C}$, as discussed later, except that for the $\alpha(\mathrm{Ti}, \mathrm{Zr})+\mathrm{Ti}_{3} \mathrm{Al} / \mathrm{Ti}_{3} \mathrm{Al}$ phase boundary. ${ }^{[75]} 9$ diffusion couples prepared for a diffusion study in b.c.c. $\beta(\mathrm{Ti}, \mathrm{Zr})$ were apparently all single-phase $\beta(\mathrm{Ti}, \mathrm{Zr})$ after annealing for $48 \mathrm{~h}$ at $1000{ }^{\circ} \mathrm{C},{ }^{[63]}$ in accordance with the composition range outlined in (Ref 24).

Finally, a ternary compound $\mathrm{Zr}_{2} \mathrm{TiAl}$ with cubic $\mathrm{L}_{1^{-}}{ }^{-}$ structure was identified in an alloy of appropriate composition that had been annealed for $480 \mathrm{~h}$ at $1000{ }^{\circ} \mathrm{C}$ and $720 \mathrm{~h}$ at $1050{ }^{\circ} \mathrm{C} \cdot{ }^{[54]}$ As discussed before, it is assumed that the composition may lie within the extended singlephase region of $\beta(\mathrm{Ti}, \mathrm{Zr})$ and therefore ordering may occur on cooling.

Figure 1 shows the diagram established in (Ref 24) together with all other results from investigations at this temperature. Figure 2 shows the isothermal section as assessed from the results discussed above. It is based on the one established by (Ref 24) with the phase boundaries adjusted to match with those of the accepted binaries and to be in accordance with thermodynamic rules. A small phase field for $\mathrm{Zr}_{3} \mathrm{Al}$ and respective tentative multi-phase equilibria have been added to comply with the accepted Al-Zr binary system. As it has not been settled yet, whether the compositions $\mathrm{Ti}_{2} \mathrm{AlZr}$ and $\mathrm{Zr}_{2} \mathrm{TiAl}$ are separate phases, or indicate B2-ordering at this temperature within Al-rich compositions of $\beta(\mathrm{Ti}, \mathrm{Zr}),{ }^{[52,57,59]}$ an area where $\mathrm{B} 2-$ ordering may occur has been outlined in Fig. 2.

\section{Isothermal Section at $800{ }^{\circ} \mathrm{C}$}

A complete isothermal section at $800{ }^{\circ} \mathrm{C}^{[25]}$ (Fig. 3) was determined by the same group that established the isotherm at $1000{ }^{\circ} \mathrm{C}$ using the same techniques as in (Ref 24), except that no XRD has been employed in (Ref 25). In addition, they employed a $\mathrm{Ti} / \mathrm{TiAl}_{3} / \mathrm{Zr}$ diffusion triple and this, like 12 alloys of fixed composition, was heat-treated for $2400 \mathrm{~h}$ at $800{ }^{\circ} \mathrm{C}$. Again the isotherm contains some violations concerning thermodynamic rules and determined phase boundaries for the $\mathrm{Ti}-\mathrm{Al}$ phases are not in good agreement with the accepted binary system, ${ }^{[27]}$ particular in showing a much lower solid solubility of $\mathrm{Al}$ in $\alpha$ (Ti). Also at $800{ }^{\circ} \mathrm{C}$ no ternary phases are observed while all binary phases have considerable solid solubility ranges, with the exception of $\mathrm{Zr}_{2} \mathrm{Al}_{3}$ and $\mathrm{ZrAl}$. The latter phase was not detected at all, presumably because of its limited homogeneity range in the ternary system. All ternary homogeneity ranges of the binary $\mathrm{Zr}$-Al phases show a pronounced tendency for substitution of $\mathrm{Zr}$ by $\mathrm{Ti}$, except $\mathrm{ZrAl}_{2}$, which shows a pronounced tendency for substitution of $\mathrm{Al}$ by Ti (Fig. 3). Though a complete isotherm has been established, many three-phase fields have not been experimentally confirmed (dashed triangles in Fig. 3). Therefore it could be theoretically possible that instead of the two-phase equilibrium $\beta(\mathrm{Ti}, \mathrm{Zr})+\mathrm{Zr}_{4} \mathrm{Al}_{3}$ the phases $\mathrm{ZrAl}_{2}$ and $\mathrm{Zr}_{3} \mathrm{Al}_{2}$ are in equilibrium with each other. The solubility for $\mathrm{Zr}$ in $\mathrm{TiAl}_{2}$ is 11.2 at.\%, which is about the same value as at $1000{ }^{\circ} \mathrm{C} .{ }^{[24]}$ The solubility for $\mathrm{Ti}$ in $\mathrm{Zr}_{2} \mathrm{Al}$ is 13.8 at.\%, somewhat higher than at $1000{ }^{\circ} \mathrm{C} \cdot{ }^{[24]}$ Solid solubilities of the third element in other binary phases could actually even be higher than indicated in Fig. 3, as the maxima shown there stem either from phase equilibria shown by dashed lines, i.e. experimentally not determined, or from evaluating the diffusion path in the diffusion triple. As the diffusion path will always cross two-phase fields, established compositions can be more or less close to the three-phase equilibrium and therefore do not correspond to a maximum solid solubility in a phase.

Otherwise, there are few other data available for this temperature, mostly for the $\mathrm{Ti}$ corner. The effect of $\mathrm{Zr}$ addition on the $\alpha(\mathrm{Ti}, \mathrm{Zr}) / \alpha(\mathrm{Ti}, \mathrm{Zr})+\mathrm{Ti}_{3} \mathrm{Al}$ phase boundary 
Fig. 1 (a) Isothermal section at $1000{ }^{\circ} \mathrm{C}$ according to ${ }^{[24]}$ with additional experimental results from the literature. (b) Enlarged area from this figure showing phase equilibria and experimental results for $\mathrm{TiAl}$ in more detail

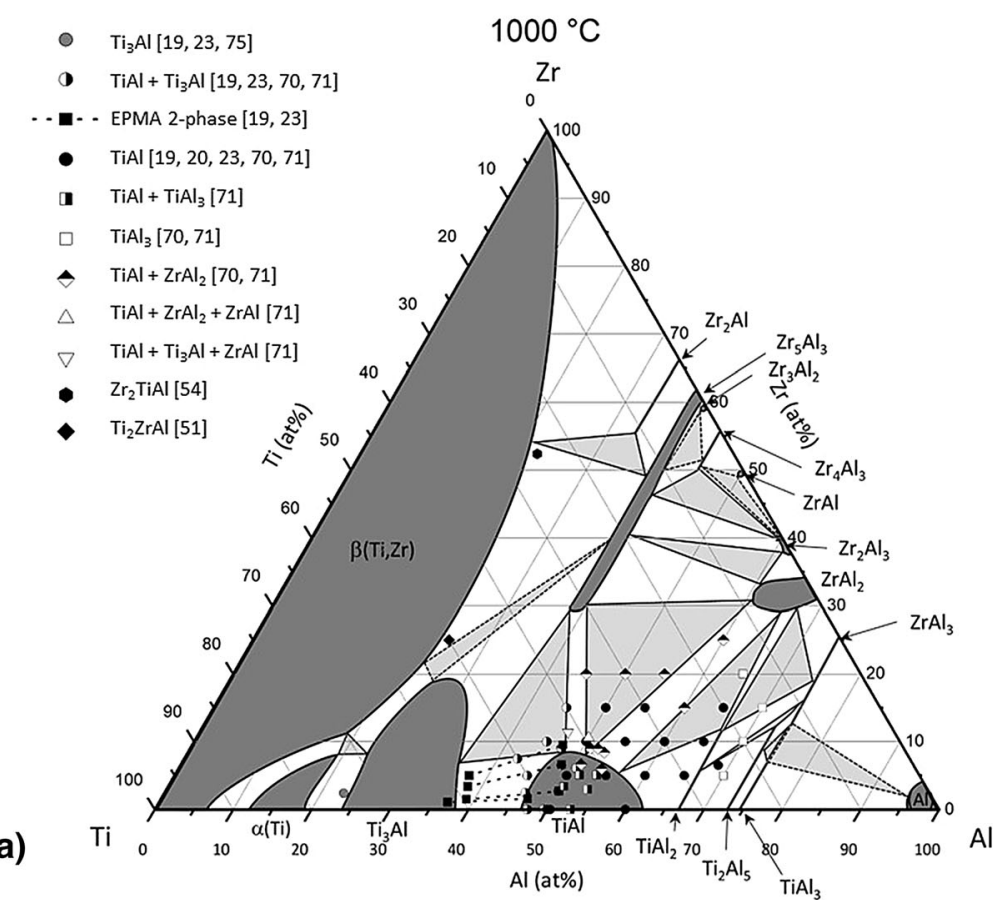

(a)

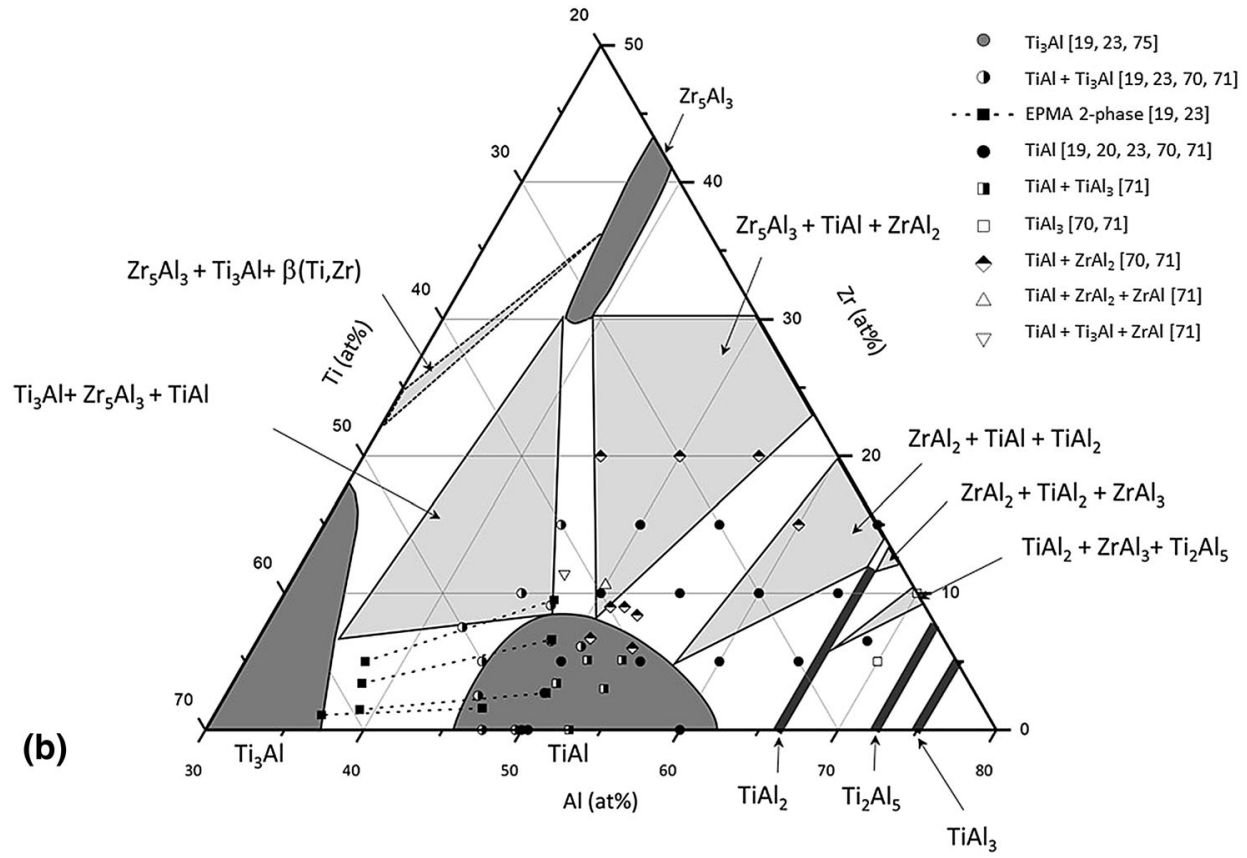

was investigated in (Ref 2) in the composition range $\mathrm{Ti}-(8-13) \mathrm{Al}-(1-2) \mathrm{Zr}$ at.\%. Alloys were produced by arcmelting and rolled prior to annealing at $800{ }^{\circ} \mathrm{C}$ for $200 \mathrm{~h}$ under flowing Ar. Chemical analyses after heat treatment were in good agreement with the nominal compositions and the amount of oxygen was assumed to be 0.03 to 0.04 wt.\%. By light microscopy it was established that all investigated alloys were single-phase $\alpha(\mathrm{Ti}, \mathrm{Zr})$ at $800{ }^{\circ} \mathrm{C}$. This shows that $\alpha(\mathrm{Ti}, \mathrm{Zr})$ extends to somewhat more $\mathrm{Zr}$-rich and markedly more Al-rich compositions than shown in Fig. 3, in good agreement with the accepted binary Ti-Al system. ${ }^{[27]}$

Quite a couple of vertical sections exist, which include results at $800{ }^{\circ} \mathrm{C}^{[64,72-76]}$ Though, all of them either 
missed out some phases and/or phase equilibria, denote data points to other phase boundaries than those shown in Fig. 3 or are contradictory in itself (for a detailed discussion see section on Vertical Sections). However, as far as the Ti corner has been investigated, they are inline that $\alpha(\mathrm{Ti}, \mathrm{Zr})$ extends further into the ternary system than shown in (Ref 25).

Four samples in the $\mathrm{Al}$ corner of compositions 0-15Ti$\mathrm{Al}-5 \mathrm{Zr}$ (at.\%) were investigated in (Ref 77). The samples were prepared by annealing pre-cursors pressed from elemental powders at $800{ }^{\circ} \mathrm{C}$ for $30 \mathrm{~min}$. Samples were analysed by observations in a scanning electron microscope (SEM), XRD and electron-dispersive X-ray spectroscopy (EDS). All alloys consist of the two phases $\mathrm{Al}+(\mathrm{Zr}, \mathrm{Ti}) \mathrm{Al}_{3}$. According to the isothermal section by Lü et al., (Ref 25) the two Ti-rich compositions should show the three-phase equilibrium $\mathrm{Al}+(\mathrm{Zr}, \mathrm{Ti}) \mathrm{Al}_{3}$ $+\mathrm{TiAl}_{3}$ at $800{ }^{\circ} \mathrm{C}$ (Fig. 3). One explanation for this discrepancy could be that the annealing time of 30 min was too short to attain equilibrium.

The isothermal section assessed here is shown in Fig. 4. It is based on the results by (Ref 25) with an increased solid solubility range for $\alpha(\mathrm{Ti}, \mathrm{Zr})$, in agreement with (Ref 2 ) and the binary Al-Ti system. Phase boundaries have been adjusted to match with those of the accepted binaries and to be in accordance with thermodynamic rules.

\section{Data at Temperatures Below $800{ }^{\circ} \mathrm{C}$}

As attaining thermodynamic equilibrium in Al-Ti-Zr alloys at low temperatures becomes more and more difficult, data on phase equilibria below $800{ }^{\circ} \mathrm{C}$ are scarce. The effect of $\mathrm{Zr}$ addition on the $\alpha(\mathrm{Ti}, \mathrm{Zr}) / \alpha(\mathrm{Ti}, \mathrm{Zr})+\mathrm{Ti}_{3} \mathrm{Al}$ phase boundary in the temperature range $500-700{ }^{\circ} \mathrm{C}$ is shown in (Ref 2), which also shows a partial isothermal section at $700{ }^{\circ} \mathrm{C}$. The phase boundary matches well with the accepted binary. ${ }^{[27]}$ From a series of 16 alloys equilibrated for $500 \mathrm{~h}$ at $700{ }^{\circ} \mathrm{C}$, the phase boundaries of the two-phase field $\alpha(\mathrm{Ti}, \mathrm{Zr})+\mathrm{Ti}_{3} \mathrm{Al}$ with up to $5 \mathrm{wt} \% \mathrm{Zr}$ were determined. ${ }^{[75]}$ Compared to the binary system, the two phase area widens by the addition of $\mathrm{Zr}$, in line with the observation by (Ref 2$)$. The $\alpha(\mathrm{Ti}, \mathrm{Zr}) / \alpha(\mathrm{Ti}, \mathrm{Zr})+\mathrm{Ti}_{3} \mathrm{Al}$ phase boundary was also studied at $600{ }^{\circ} \mathrm{C}$ by equilibrating alloys with 2, 6 and 10 at.\% $\mathrm{Zr}$ for 400 h. ${ }^{[78]}$ The extrapolated phase boundary matches well with the extrapolated
Fig. 2 Critically assessed isothermal section of the Al-Ti-Zr system at $1000{ }^{\circ} \mathrm{C}$

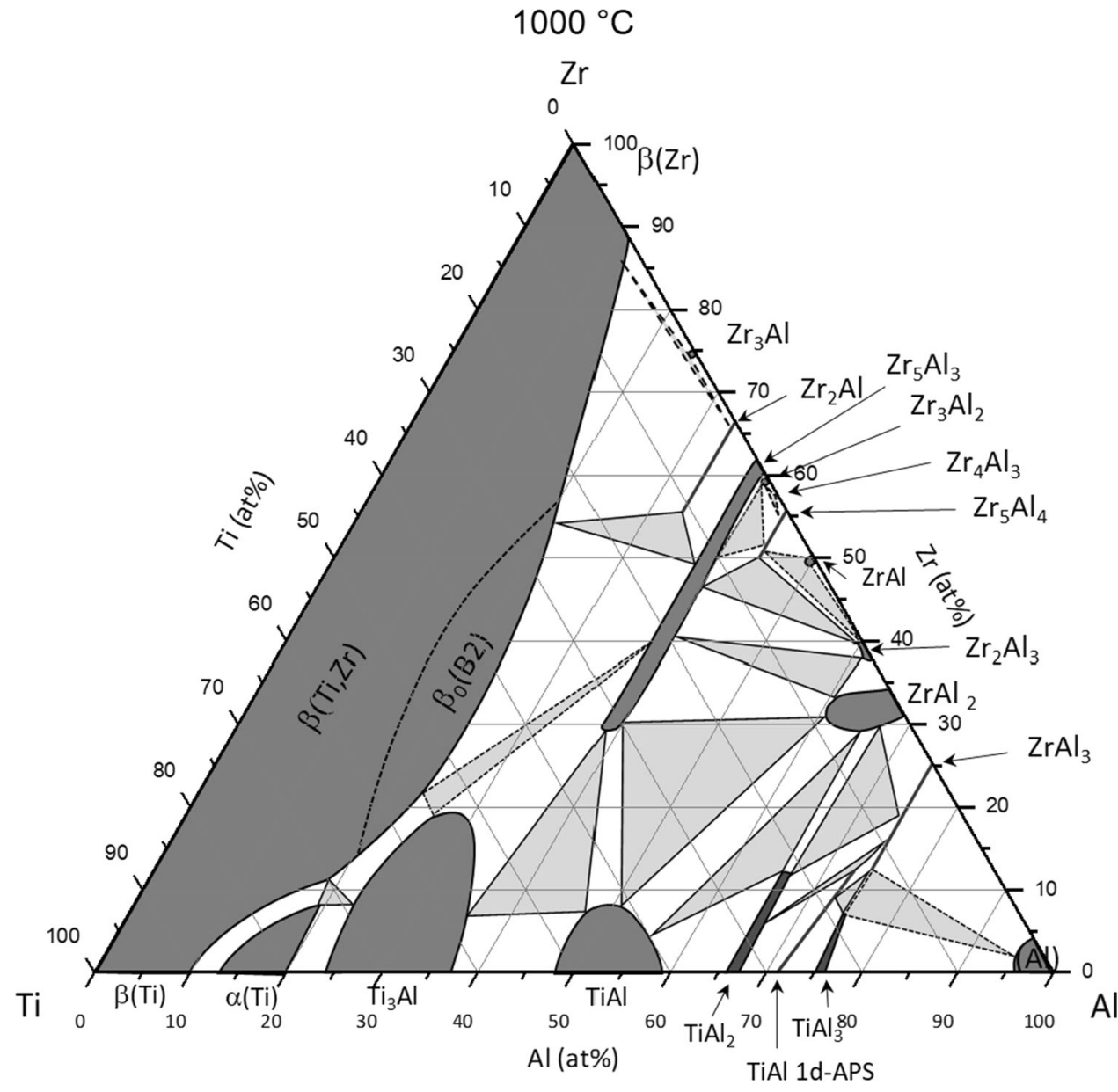


one in the binary Al-Ti system. ${ }^{[27]} \mathrm{A}$ partial isothermal section of the Ti-corner at $500{ }^{\circ} \mathrm{C}$ showing the $\alpha(\mathrm{Ti}, \mathrm{Zr})+\mathrm{Ti}_{3} \mathrm{Al}$ phase area is included in (Ref 75).

\section{Data at Temperatures Above $1000{ }^{\circ} \mathrm{C}$}

Information above $1000{ }^{\circ} \mathrm{C}$ is limited to phase equilibria between the phases $\alpha(\mathrm{Ti}, \mathrm{Zr}), \beta(\mathrm{Ti}, \mathrm{Zr})$ and TiAl. The phase relations between these phases have been studied by investigating alloys annealed at $1200{ }^{\circ} \mathrm{C}$ for $168 \mathrm{~h}$ and at

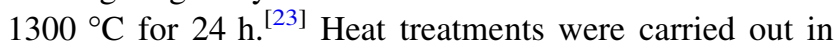
quartz capsules, which are usually considered not to be any longer gas-tight at these temperatures. However, oxygen and nitrogen contents were below 400 (wt.) ppm after the heat treatments. Compositions of coexisting phases in the quenched samples were determined by EPMA by averaging data from 10 points. At $1200{ }^{\circ} \mathrm{C}$ the three-phase equilibrium $\alpha(\mathrm{Ti}, \mathrm{Zr})+\beta(\mathrm{Ti}, \mathrm{Zr})+\mathrm{TiAl}$ could be determined, showing a maximum solid solubility of 5.1 at. $\% \mathrm{Zr}$ in $\alpha(\mathrm{Ti}, \mathrm{Zr})$. Though this tie-triangle was not measured directly at $1300{ }^{\circ} \mathrm{C}$, the adjacent tie-lines suggest that the solubility for $\mathrm{Zr}$ in $\alpha(\mathrm{Ti}, \mathrm{Zr})$ may only slightly increase up to about 5.5 at. $\% \mathrm{Zr}$ at this temperature.

In the diffusion study of b.c.c. $\beta(\mathrm{Ti}, \mathrm{Zr}),{ }^{[63]} 11$ diffusion couples were annealed for $17 \mathrm{~h}$ at $1200{ }^{\circ} \mathrm{C}$. All of them were single-phase $\beta(\mathrm{Ti}, \mathrm{Zr})$ after annealing, in accordance with the $\beta(\mathrm{Ti}, \mathrm{Zr}) / \beta(\mathrm{Ti}, \mathrm{Zr})+\alpha(\mathrm{Ti}, \mathrm{Zr})$ and $\beta(\mathrm{Ti}, \mathrm{Zr}) /$ $\beta(\mathrm{Ti}, \mathrm{Zr})+$ TiAl phase boundaries determined by (Ref 23 ) for lower $\mathrm{Zr}$ contents.

An arc melted alloy of the composition Ti-24.8Al$24.9 \mathrm{Zr}$ at. \% that was solution treated at $1200{ }^{\circ} \mathrm{C}$ for $30 \mathrm{~min}$ and water quenched, was found to be single-phase B2ordered $\beta(\mathrm{Ti}, \mathrm{Zr})$ by $\mathrm{TEM}^{[52]}$ As no anti-phase domains were observed, the authors concluded that the alloy has been $\mathrm{B} 2$ at $1200{ }^{\circ} \mathrm{C}$ and did not undergo ordering at lower temperatures during quenching.

In a couple of early studies, the extension of the TiAl phase field at $1093{ }^{\circ} \mathrm{C}^{[79]}$ and $1274{ }^{\circ} \mathrm{C}^{[18,28]}$ was studied by metallography and XRD. At $1093{ }^{\circ} \mathrm{C}, 27$ different alloys were heat treated for 36-39 $\mathrm{h}$ and air cooled. ${ }^{[79]}$ The maximum solid solubility for $\mathrm{Zr}$ in TiAl was found to be about 8 at\% at $1093{ }^{\circ} \mathrm{C} .{ }^{[79]}$ A first partial isothermal section for " $1274{ }^{\circ} \mathrm{C}$ " was constructed from 19 alloys, which were actually heat treated between 1246 and $1379{ }^{\circ} \mathrm{C}$ for 24-39 h. ${ }^{[28]}$ The partial isothermal section for $1274{ }^{\circ} \mathrm{C}$ was updated by 18 alloys, which were wrapped in Ta foil and encapsulated in quartz ampules for the heat treatments and which were quenched in brine after annealing for $24 \mathrm{~h}^{[18]}$ As the determined composition range for TiAl in the binary system is shifted markedly to higher Al contents compared to the currently accepted one, ${ }^{[27]}$ the established solid solubility limit of about 13 at. $\% \mathrm{Zr}$ in $\mathrm{TiAl}$ at $1274{ }^{\circ} \mathrm{C}^{[18]}$ could be doubted. For establishing various vertical sections, quite a couple of alloys have been studied, which have been equilibrated at $1100{ }^{\circ} \mathrm{C} .{ }^{[64,72,73,75]}$ As discussed in more detail in the following section, these results are all considered to be questionable.

\section{Vertical Sections}

\subsection{Sections Towards the $\mathrm{Zr}$ Corner}

The vertical section Ti-14.9 at.\% $\mathrm{Al} / \mathrm{Zr}$ was investigated between 500 and $1100{ }^{\circ} \mathrm{C}$ by metallography of 19 different annealed alloys and thermal analysis. ${ }^{[72]}$ Established phase boundaries do not match at $800{ }^{\circ} \mathrm{C}$ with the current knowledge of the binary Ti-Zr system or the ternary system (Fig. 4) with the sole exception of the $\beta(\mathrm{Ti}, \mathrm{Zr}) /$ $\alpha(\mathrm{Ti}, \mathrm{Zr})+\beta(\mathrm{Ti}, \mathrm{Zr})$ phase boundary. Therefore, the location of the minimum in the $\alpha(\mathrm{Ti}, \mathrm{Zr}) / \beta(\mathrm{Ti}, \mathrm{Zr})$ transformation temperature of about $660{ }^{\circ} \mathrm{C}$ and $65 \mathrm{wt} \% \mathrm{Zr}$ may be doubtful. A comparable minimum was found in the vertical section Ti-25.3 at.\% $\mathrm{Al} / \mathrm{Zr}$ at about $515{ }^{\circ} \mathrm{C}$ and $70 \mathrm{wt} \%$ $\mathrm{Zr} .{ }^{[55]}$ In this study, the vertical section has been determined between 500 and $1900{ }^{\circ} \mathrm{C}$ by thermal analysis of 11 alloys and microstructural and XRD investigations of quenched alloys. ${ }^{[55]}$ Beside determination of the solidus temperatures, phase boundaries of the $\alpha(\mathrm{Ti}, \mathrm{Zr})$, $\alpha(\mathrm{Ti}, \mathrm{Zr})+\beta(\mathrm{Ti}, \mathrm{Zr})$, and $\beta(\mathrm{Ti}, \mathrm{Zr})$ phase fields were determined. The melting temperature determined for $\mathrm{Zr}$ $\left(1850{ }^{\circ} \mathrm{C}\right)$ and the solidus temperature of $\mathrm{Ti}_{3} \mathrm{Al}$ with 24.1 at.\% $\mathrm{Al}\left(\sim 1650{ }^{\circ} \mathrm{C}\right)$ are very close to the currently accepted values $1855{ }^{\circ} \mathrm{C}^{[80]}$ and $1655^{\circ} \mathrm{C}^{[27]}$ Therefore, remaining solidus and liquidus temperatures determined in (Ref 55) may be considered as relevant. Though the existence of the compound $\mathrm{Ti}_{3} \mathrm{Al}$ has been realised in (Ref 55), the phase has not been included in the vertical section. Also, according to the isotherms at $800{ }^{\circ} \mathrm{C}$ and $1000{ }^{\circ} \mathrm{C}$ shown in Fig. 2 and 4, this vertical section should include phase equilibria with quite a number of other phases e.g. TiAl or $\mathrm{Zr}(\mathrm{Al}, \mathrm{Ti})_{2}$. As no other phases than $\alpha(\mathrm{Ti}, \mathrm{Zr})$ and $\beta(\mathrm{Ti}, \mathrm{Zr})$ are shown in the section, solid phase equilibria from ${ }^{[55]}$ are not further considered here. One more "tentative" section along Ti-33.3 at.\% $\mathrm{Al} / \mathrm{Zr}^{[64]}$ was constructed from 20 samples annealed between 500 and $1100{ }^{\circ} \mathrm{C}$, which were analyzed by metallography and partly by XRD, supplemented by data from thermal analysis. The section had been tentative, as many alloys underwent phase transformations during cooling and therefore phase equilibria at the annealing temperature were not clear. Again the section misses out phase equilibria with the phases originating in the Al-Zr binary system, with the exception of $\mathrm{Zr}_{3} \mathrm{Al}$, which according to this section would coexist 
Fig. 3 Isothermal section at $800{ }^{\circ} \mathrm{C}$ according to (Ref 25) with additional experimental results from the literature

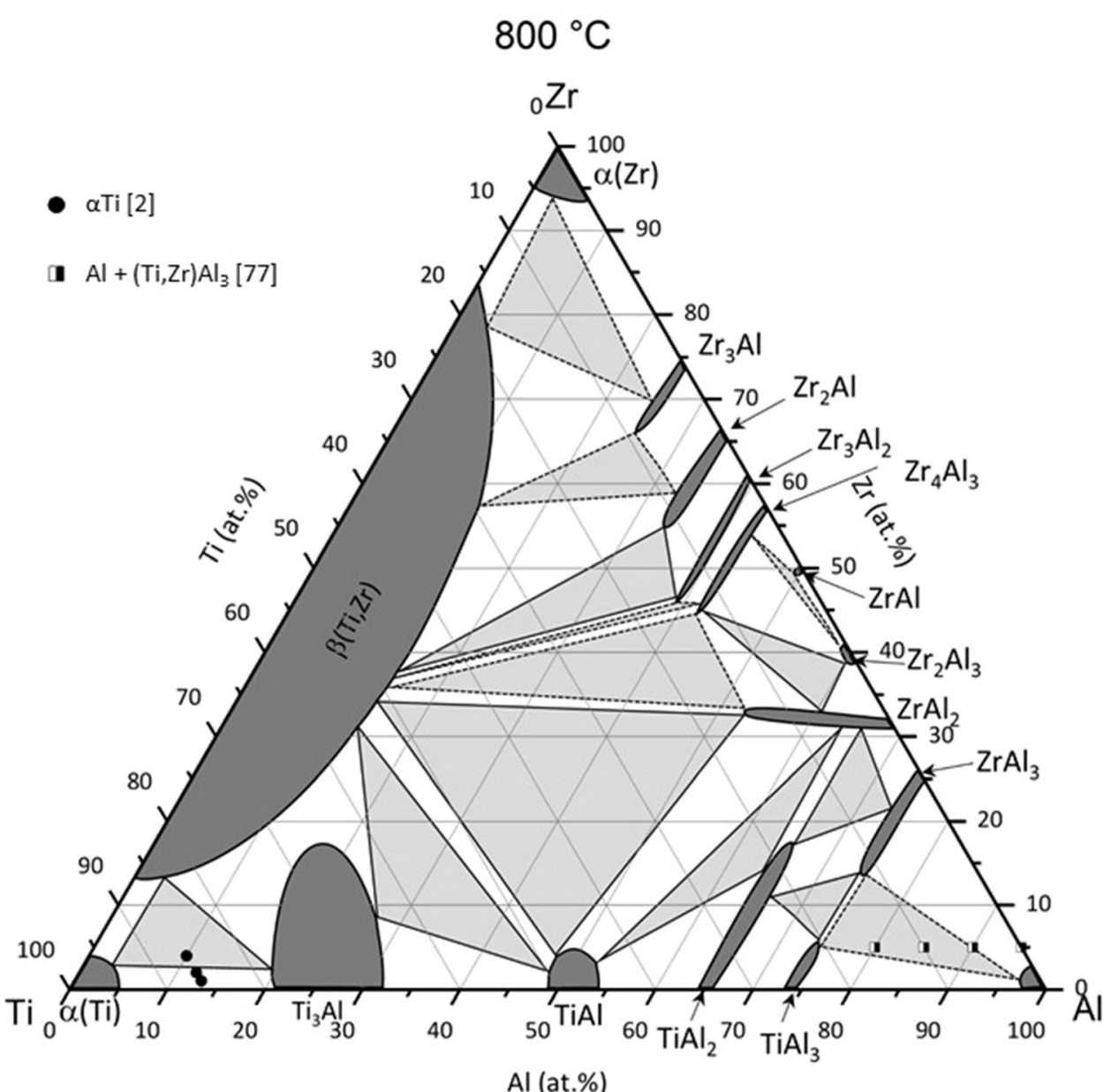

over a large composition range with $\alpha(\mathrm{Ti}, \mathrm{Zr})$ and $\beta(\mathrm{Ti}, \mathrm{Zr}){ }^{[64]}$

In the vertical sections Ti/Ti-49.4 at.\% $\mathrm{Zr}$ containing 0 , 6.9 , and 9.6 at.\% $\mathrm{Al}$ the phase boundaries for $\alpha(\mathrm{Ti}, \mathrm{Zr})$ and $\beta\left(\mathrm{Ti}, \mathrm{Zr}\right.$ ) between 600 and $\sim 1100{ }^{\circ} \mathrm{C}$ were determined by metallography of annealed samples and additional dilatometry for the binary section. ${ }^{[76]}$ All phase boundaries show a sharp increase in temperature between 0 and about 1 at.\% $\mathrm{Zr}$, e.g. about $45 \mathrm{~K}$ for $\alpha(\mathrm{Ti}, \mathrm{Zr}) / \alpha(\mathrm{Ti}, \mathrm{Zr})+$ $\beta(\mathrm{Ti}, \mathrm{Zr})$, and then temperatures decrease steadily to 49.4 at. $\% \mathrm{Zr}$. As far as temperatures can be read from the diagram, they seem not to match phase boundaries shown for $800{ }^{\circ} \mathrm{C}$ and $1000{ }^{\circ} \mathrm{C}$ in Fig. 2 and 4 and as a peak in temperature in the $\alpha(\mathrm{Ti}, \mathrm{Zr})$ and $\beta(\mathrm{Ti}, \mathrm{Zr})$ phase boundaries is thermodynamically improbable, results of (Ref 76) are not further considered here.

\subsection{Sections Towards the Al Corner}

Based on metallography on heat treated samples quenched from 800, 1000, 1100 and $1200{ }^{\circ} \mathrm{C}$, thermal analysis and dilatometry, two vertical sections for $\mathrm{Ti}-2.7$ at.\% $\mathrm{Zr} / \mathrm{Ti}$ -
25.3 at.\% $\mathrm{Al}$ between 700 and $1750{ }^{\circ} \mathrm{C}$ and for Ti-2.7 at.\% $\mathrm{Zr} / \mathrm{Ti}-25.8$ at.\% Al, 2.4 at.\% $\mathrm{Zr}$ between 500 and $1200{ }^{\circ} \mathrm{C}$ were determined. ${ }^{[73]}$ Results of the former section were also published in (Ref 81) and in some more detail in (Ref 74). The latter section showing additional data for $700{ }^{\circ} \mathrm{C}$ was also published in (Ref 75). Though single data points fit well to data shown in Fig. 2 and 4, the general sequence of phase equilibria is not correct. While the phase equilibrium $\alpha(\mathrm{Ti}, \mathrm{Zr})+\beta(\mathrm{Ti}, \mathrm{Zr})+\mathrm{Ti}_{3} \mathrm{Al}$ is detected at $1000{ }^{\circ} \mathrm{C}$ in the former, i.e. more $\mathrm{Zr}$ lean section, it does not show up at this temperature in the latter, i.e. the more $\mathrm{Zr}$ rich one, which only shows the three-phase equilibrium at higher temperatures. According to Fig. 2, the three phase equilibrium should either be present in both sections or only in the more $\mathrm{Zr}$-rich one, but not vice versa as shown in (Ref 73-75,81).

The $\alpha(\mathrm{Ti}, \mathrm{Zr}) / \beta(\mathrm{Ti}, \mathrm{Zr})$ phase boundaries in the vertical section $\mathrm{Ti}-2.3$ at.\% $\mathrm{Al} / \mathrm{Ti}-20$ at.\% $\mathrm{Al}, 2.3$ at.\% $\mathrm{Zr}$ were calculated in the temperature range $850-1000{ }^{\circ} \mathrm{C}$ and verified by analysing three alloys. ${ }^{[82]}$ Comparison of the $\alpha(\mathrm{Ti}, \mathrm{Zr}) / \beta(\mathrm{Ti}, \mathrm{Zr})$ phase boundaries at $1000{ }^{\circ} \mathrm{C}$ shows that they fit quite well to those shown in Fig. 2. The shift of the 
Fig. 4 Critically assessed isothermal section of the $\mathrm{Al}-\mathrm{Ti}-\mathrm{Zr}$ system at $800{ }^{\circ} \mathrm{C}$

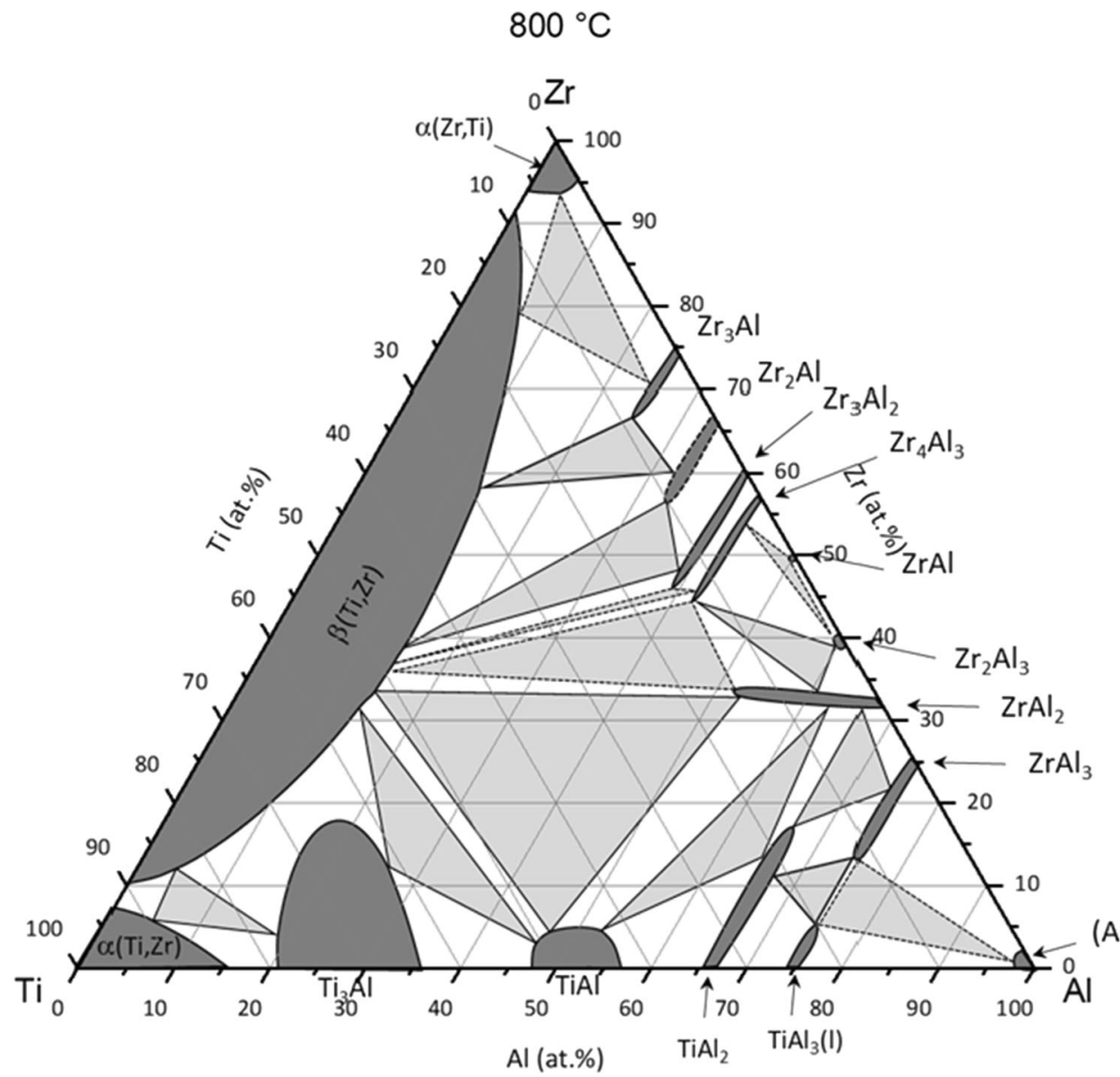

$\alpha(\mathrm{Ti}, \mathrm{Zr}) / \alpha(\mathrm{Ti}, \mathrm{Zr})+\mathrm{Ti}_{3} \mathrm{Al}$ phase boundary towards higher temperatures and lower $\mathrm{Al}$ contents with increasing $\mathrm{Zr}$ content is shown for the temperature range $500-700{ }^{\circ} \mathrm{C}$ in [2].

\section{Modelling}

Recently, CALPHAD-type and ab initio calculations were applied to establish isothermal sections at 800 and $1000{ }^{\circ} \mathrm{C}$, partial isothermal sections of the Ti-corner at 1000,1200 and $1300{ }^{\circ} \mathrm{C}$ and a vertical section along Ti-2.7 at.\% $\mathrm{Zr} / \mathrm{Ti}_{3} \mathrm{Al}^{\left[{ }^{[3]}\right.}$ Thermodynamic parameters from binaries were extracted from (Ref 41, 34,84) for Ti-Al, Al-Zr, and $\mathrm{Ti}-\mathrm{Zr}$, respectively. Experimental data from ${ }^{[23-25,52,74]}$ have been used to optimize thermodynamic parameters using the CALPHAD approach.

According to the modelling, the phase field of $\alpha(\mathrm{Ti}, \mathrm{Zr})$ extends much further into the ternary system at $800{ }^{\circ} \mathrm{C}$ compared to (Ref 25), in line with the discussion of this section above. Also $\beta(\mathrm{Ti}, \mathrm{Zr})$ extends somewhat more into the ternary system at $800{ }^{\circ} \mathrm{C}$, i.e. has a bit higher solid solubility for $\mathrm{Al}$ than shown in (Ref 25). The major difference between the isothermal sections for $800{ }^{\circ} \mathrm{C}$, are that the experimental one shows phase equilibria between $\beta(\mathrm{Ti}, \mathrm{Zr})$ and $\mathrm{Zr}(\mathrm{Al}, \mathrm{Ti})_{2},{ }^{[25]}$ while the calculations show that $\mathrm{TiAl}$ should be in equilibrium with $\mathrm{Zr}_{4} \mathrm{Al}_{3}{ }^{[83]}$ Therefore, multiphase equilibria in a wide range of compositions in the two isotherms are quite different from each other as discussed in (Ref 83). Which of the two versions is correct cannot be decided on the existing evidence.

Modelled $^{[83]}$ and experimentally determined ${ }^{[24]}$ isothermal sections at $1000{ }^{\circ} \mathrm{C}$ qualitatively match much better. Though, there are some differences in the solid solubility ranges of individual phases, most notably for $\mathrm{Ti}_{3} \mathrm{Al}$, which has less solid solubility for $\mathrm{Zr}$ according to the modelling. Otherwise, all multiphase equilibria in the experimental section are reproduced in the modelling. At higher temperatures there is quite some discrepancy at $1200{ }^{\circ} \mathrm{C}$ between the modelling ${ }^{[83]}$ and experimental data in the Ti-corner ${ }^{[23]}$ while the match at $1300{ }^{\circ} \mathrm{C}$ is somewhat better. Calculated phase boundaries at 800 and $1000{ }^{\circ} \mathrm{C}$ of the vertical section ${ }^{[83]}$ fit very well with those of the binary accepted here, with the sole exception for the $\alpha(\mathrm{Ti}) / \alpha(\mathrm{Ti})+\mathrm{Ti}_{3} \mathrm{Al}$ phase boundary at $800{ }^{\circ} \mathrm{C}$, which according to Fig. 4 should be at a somewhat lower $\mathrm{Al}$ content. 
A vertical section along $(\mathrm{Ti}, \mathrm{Zr}) \mathrm{Al}_{3}$ has been calculated for $900-1100{ }^{\circ} \mathrm{C} .{ }^{[85]}$ In this section the two-phase field $\mathrm{D}_{22}+\mathrm{DO}_{23}$ is located much closer to the $\mathrm{TiAl}_{3}\left(\mathrm{DO}_{22}\right)$ side than in the experimentally determined section at $1000{ }^{\circ} \mathrm{C}$ (Fig. 1). ${ }^{[24]}$ The relative stability of the $\mathrm{L} 1_{2}, \mathrm{D} 0_{22}$ and $\mathrm{DO}_{23}$ structures along $\mathrm{TiAl}_{3}-\mathrm{ZrAl}_{3}$ was investigated at $0 \mathrm{~K}$ by calculating the enthalpy of formation using first principles calculations. ${ }^{[86]}$ The results indicate that the $\mathrm{D}_{23}$ structure is the most stable along the complete section. While this finding agrees with experimental evidence for $\mathrm{ZrAl}_{3}$, it is in contradiction for $\mathrm{TiAl}_{3}$, where $\mathrm{DO}_{23}$ is known to be the high-temperature polymorph while at lower temperatures $\mathrm{D}_{22}$ becomes stable. This discrepancy between ab initio calculations and experiments in case of $\mathrm{TiAl}_{3}$ is well known and also discussed in (Ref 86).

Wang et al. (Ref 97) developed a thermodynamic description of the Al-Ti-Zr system, which was employed for reproducing the isothermal and vertical sections determined in (Refs 23-25, 74). In addition, the atomic mobility for $\beta(\mathrm{Ti}, \mathrm{Zr})$ has been assessed for the calculation of diffusion coefficients and diffusion paths determined in (Ref. 63) have been calculated. Also very recently, Abreu et al. (Ref 98) established the first liquidus projection of the system, based on detailed analysis of the microstructures of 27 as-cast alloys.

Acknowledgment The authors gratefully acknowledge funding from the Clean Sky 2 Joint Undertaking under the European Union's Horizon 2020 research and innovation program under Grant agreement No 820647 .

Open Access This article is licensed under a Creative Commons Attribution 4.0 International License, which permits use, sharing, adaptation, distribution and reproduction in any medium or format, as long as you give appropriate credit to the original author(s) and the source, provide a link to the Creative Commons licence, and indicate if changes were made. The images or other third party material in this article are included in the article's Creative Commons licence, unless indicated otherwise in a credit line to the material. If material is not included in the article's Creative Commons licence and your intended use is not permitted by statutory regulation or exceeds the permitted use, you will need to obtain permission directly from the copyright holder. To view a copy of this licence, visit http://creativecommons. org/licenses/by/4.0/.

Funding Open Access funding enabled and organized by Projekt DEAL.

\section{References}

1. I.I. Kornilov, Physical metallurgy of titanium (Metalovideniye Titana), in 5th Conference on Metallurgy, Physical Metallurgy, and Application of Titanium and its Alloys, ed. by I.I. Kornilov (National Aeronautics and Space Administration, Moscow, 1963), pp. 1-351
2. F.A. Crossley, Effects of the Ternary Additions: $\mathrm{O}, \mathrm{Sn}, \mathrm{Zr}, \mathrm{Cb}$, Mo and $\mathrm{V}$ on the $\alpha / \alpha+\mathrm{Ti}_{3} \mathrm{Al}$ Boundary of Ti-Al Base Alloys, Trans. Metall. Soc. AIME, 1969, 245(9), p 1963-1968

3. G.K. Scarr, J.C. Williams, S. Ankem, and H.B. Bomberger, The effect of zirconium and oxygen on $\mathrm{a}_{2}$ precipitation in titaniumaluminum alloys, in 5th Interntional Conference on Titanium, eds. by G. Lütjering, U. Zwicker, W. Bunk (DGM, Munich, Germany, 1985), pp. 1475-1479

4. S. Tsunekawa and M.E. Fine, Lattice Parameters of $\mathrm{Al}_{3}\left(\mathrm{Zr}_{\mathrm{x}} \mathrm{Ti}_{1-\mathrm{x}}\right)$ vs. $\mathrm{x}$ in Al-2 at.\% (Ti $+\mathrm{Zr})$ Alloys, Scr. Metall., 1982, 16, p 391-392

5. V.R. Parameswaran, J.R. Weertman, and M.E. Fine, Coarsening Behavior of $\mathrm{L1}_{2}$ Phase in an Al-Zr-Ti Alloy, Scr. Metall., 1989, 23, p 147-150

6. K.M. Lee, J.H. Lee, and I.H. Moon, Effects of V and Zr Addition on Lattice Parameters of $\mathrm{Al}_{3} \mathrm{Ti}$ Phase in Mechanically Alloyed Al-8 wt\% Ti Alloys, Scr. Metall. Mater., 1993, 29, p 737-740

7. P. Málek, M. Janecek, B. Smola, P. Bartuska, and J. Plestil, Structure and Properties of Rapidly Solidified Al-Zr-Ti Alloys, $J$. Mater. Sci., 2000, 35, p 2625-2633

8. A.A. Abdel-Hamid, Crystallization of Complex Aluminide Compounds from Dilute Al-Ti Melts Containing One or Two Other Transition Metals of IVB to VIB Groups, Z. Metallkd., 1990, 81(8), p 601-605

9. B. Dubost, Applications industrielles et détermination des diagrammes d'équilibre de phases des alliages légers Progrès et perspectives (Industrial Applications and Determination of Equilibrium Phase Diagrams for Light Alloys Progress and Prospects), Rev. Metall. (Paris), 1993, 90(2), p 195-209 (in French)

10. L. Zhang, D.G. Eskin, and L. Katgerman, Influence of Ultrasonic Melt Treatment on the Formation of Primary Intermetallics and Related Grain Refinement in Aluminum Alloys, J. Mater. Sci., 2011, 46, p 5252-5259

11. G.J. Fan, X.P. Song, M.X. Quan, and Z.Q. Hu, Mechanical Alloying and Thermal Stability of $\mathrm{Al}_{67} \mathrm{Ti}_{25} \mathrm{M}_{8}(\mathrm{M}=\mathrm{Cr}, \mathrm{Zr}, \mathrm{Cu})$, Mater. Sci. Eng., A, 1997, 231, p 111-116

12. M.V. Karpets, Y.V. Milman, O.M. Barabash, N.P. Korzhova, O.N. Senkov, D.B. Miracle, T.N. Legkaya, and I.V. Voskoboynik, The Influence of $\mathrm{Zr}$ Alloying on the Structure and Properties of $\mathrm{Al}_{3} \mathrm{Ti}$, Intermetallics, 2003, 11, p 241-249

13. S.S. Nayak, S.K. Pabi, and B.S. Murty, High Strength Nanocrystalline L12-Al3(Ti, Zr) Intermetallic Synthesized by Mechanical Alloying, Intermetallics, 2007, 15, p 26-33

14. K.E. Knipling, D.C. Dunand, and D.N. Seidman, Precipitation Evolution in $\mathrm{Al}-\mathrm{Zr}$ and $\mathrm{Al}-\mathrm{Zr}-\mathrm{Ti}$ Alloys During Aging at 450-600 ${ }^{\circ}$, Acta Mater., 2008, 56, p 1182-1195

15. E.A. Popova, A.B. Shubin, P.V. Kotenkov, E.A. Pastukhov, L.E. Bodrova, and O.M. Fedorova, Al-Ti-Zr Master Alloys: Structure Formation, Russ. Metall. (Engl. Transl.), 2012, 2012(5), p 357-361

16. E.A. Popova, P.V. Kotenkov, E.A. Pastukhov, and A.B. Shubin, Master Alloys Al-Sc-Zr, Al-Sc-Ti, and Al-Ti-Zr: Their Manufacture, Composition, and Structure, Russ. Metall. (Engl. Transl.), 2013, 13(8), p 590-594

17. P. Kotenkov, E. Popova, and I. Gilev, Formation of stable and metastable aluminides in $\mathrm{Al}-\mathrm{Zr}-\mathrm{Ti}, \mathrm{Al}-\mathrm{Ti}-\mathrm{Nb}$ alloys, in Physics, Technologies and Innovation (PTI-2018): Proceedings of the $V$ International Young Researchers' Conference, eds. by V.A. Volkovich, S.V. Zvonarev, I.V. Kashin, E.D. Narkhov (Ekaterinburg, Russia, 2018), p. 020046

18. S.V. Spragins, J.R. Myers, and R.K. Saxer, Influence of Zirconium Additions on the Epsilon Phase of the Titanium-Aluminium System, Nature Lett., 1965, 4993(10), p 183-184

19. K. Hashimoto, H. Doi, K. Kasahara, T. Tsujimoto, and T. Suzuki, Effects of Third Elements on the Structures of TiAl-Based 
Alloys, Nippon Kinzoku Gakkaishi (J. Jpn. Inst. Met.), 1988, 52(8), p 816-825 (in Japanese)

20. H. Doi, K. Hashimoto, K. Kasahara, and T. Tsujimoto, Site Determination of Third Elements in TiAl Compound by X-ray Diffractometry, Mater. Trans., JIM, 1990, 31(11), p 975-982

21. X.F. Chen, R.D. Reviere, B.F. Oliver, and C.R. Brooks, The Site Location of $\mathrm{Zr}$ Atoms Dissolved in TiAI, Scr. Metall. Mater., 1992, 27, p 45-49

22. C.T. Forwood, M.A. Gibson, P.R. Miller, C.J. Rossouw, and A.J. Morton, Alloying effects and deformation processes in duplex g-TiAl alloys, in Structural Intermetallics 1997, eds. by M.V. Nathal, R. Darolia, C.T. Liu, P.L. Martin, D.B. Miracle, R. Wagner, M. Yamaguchi (Seven Springs, PA, TMS, Warrendale, PA, 1997), pp. 545-554

23. R. Kainuma, Y. Fujita, H. Mitsui, I. Ohnuma, and K. Ishida, Phase Equilibria Among a (hcp), b (bcc) and $g\left(\mathrm{~L}_{10}\right)$ Phases in TiAl Base Ternary Alloys, Intermetallics, 2000, 8, p 855-867

24. F. Yang, F.H. Xiao, S.G. Liu, S.S. Dong, L.H. Huang, Q. Chen, G.M. Cai, H.S. Liu, and Z.P. Jin, Isothermal Section of Al-Ti-Zr Ternary System at $1273 \mathrm{~K}$, J. Alloys Compd., 2014, 585, p 325-330

25. K.L. Lü, F. Yang, Z.Y. Xie, H.S. Liu, G.M. Cai, and Z.P. Jin, Isothermal Section of $\mathrm{Al}-\mathrm{Ti}-\mathrm{Zr}$ Ternary System at $1073 \mathrm{~K}$, Trans. Nonferrous Met. Soc. China, 2016, 26, p 3052-3058

26. J.L. Murray, Al-Ti system, Phase Diagrams of Binary Titanium Alloys, J.L. Murray, Ed., ASM, Washington, DC, 1987, p 12-24

27. J.C. Schuster and M. Palm, Reassessment of the Binary Aluminium-Titanium Phase Diagram, J. Phase Equilib. Diffus., 2006, 27(3), p 255-277

28. D.H. Troup, An Investigation of the Gamma Phase of the Binary Titanium-Aluminum Alloy With Zirconium Additions, M.Sc., Air University, Islamabad, 1962

29. I. Ansara, B. Grieb, and B. Legendre, Al-Ti-Zr Ternary Phase Diagram Evaluation, MSI, Materials Science International Services GmbH, Stuttgart, 1993

30. L. Tretyachenko, Al-Ti-Zr Ternary Phase Diagram Evaluation, MSI, Materials Science International Services GmbH, Stuttgart, 2004

31. J. Schuster, Al-Zr Binary Phase Diagram Evaluation, MSI, Materials Science International Services GmbH, Stuttgart, 2004

32. J. Murray, A. Peruzzi, and J.P. Abriata, The AI-Zr (AluminumZirconium) System, J. Phase Equilib., 1992, 13(3), p 277-291

33. H. Okamoto, Al-Zr, J. Phase Equilib., 2002, 23(5), p 455-456

34. T. Wang, Z.P. Jin, and J.C. Zhao, Thermodynamic Assessment of the Al-Zr Binary System, J. Phase Equilib. Diffus., 2001, 22(5), p 544-551

35. E. Fischer and C. Colinet, An Updated Thermodynamic Modeling of the Al-Zr System, J. Phase Equilib. Diffus., 2015, 36(5), p 404-413

36. R. Tamim and K. Mahdouk, Thermodynamic Reassessment of the Al-Zr Binary System, J. Therm. Anal. Calorim., 2018, 131, p 1187-1200

37. A. Janghorban, A. Antoni-Zdziobek, M. Lomello-Tafin, C. Antion, T. Mazingue, and A. Pisch, Phase Equilibria in the Aluminium-Rich Side of the Al-Zr System, J. Therm. Anal. Calorim., 2013, 114, p 1015-1020

38. A. Peruzzi, Reinvestigation of the $\mathrm{Zr}$-Rich End of the $\mathrm{Zr}-\mathrm{Al}$ Equilibrium Phase Diagram, J. Nucl. Mater., 1992, 186, p 89-99

39. A. Malfliet, A. Kozlov, and N. Lebrun, Ti-Zr Binary Phase Diagram Evaluation, MSI, Materials Science International, Stuttgart, 2015

40. B. Batalu, G. Cosmeleata, and A. Aloman, Critical Analysis of the Ti-Al Phase Diagrams, U.P.B. Sci. Bull., Series B, 2006, 68(4), p 77-90

41. V.T. Witusiewicz, A.A. Bondar, U. Hecht, S. Rex, and T.Y. Velikanova, The Al-B-Nb-Ti System: III, Thermodynamic Re- evaluation of the Constituent Binary System Al-Ti, J. Alloys Compd., 2008, 465(1-2), p 64-77

42. M. Palm, Al-Ti Binary Phase Diagram Evaluation, MSI, Materials Science International, Stuttgart, 2020

43. H. Wang, R.C. Reed, J.-C. Gebelin, and N. Warnken, On the Modelling of the Point Defects in the Ordered B2 Phase of the Ti-Al System: Combining CALPHAD with First-Principles Calculations, CALPHAD: Comput. Coupling Phase Diagr. Thermochem., 2012, 39, p 21-26

44. J.L. Murray, Calculation of the Titanium-Aluminum Phase Diagram, Metall. Trans., 1988, 19A(2), p 243-247

45. U.R. Kattner, J.-C. Lin, and Y.A. Chang, Thermodynamic Assessment and Calculation of the Ti-Al System, Metall. Trans., 1992, 23A(8), p 2081-2090

46. N. Saunders, in System Al-Ti, COST507: Thermochemical Database for Light Metal Alloys, ed. by I. Ansara (ECSC-EECEAEC, Brussles and Luxembourg, 1995), pp. 52-56

47. F. Zhang, S.L. Chen, Y.A. Chang, and U.R. Kattner, A Thermodynamic Description of the Ti-Al System, Intermetallics, 1997, 5, p 471-482

48. I. Ohnuma, Y. Fujita, H. Mitsui, K. Ishikawa, R. Kainuma, and K. Ishida, Phase Equilibria in the Ti-Al Binary System, Acta Mater., 2000, 48, p 3113-3123

49. C.M. Fang and Z. Fan, An Ab Initio Study on Stacking and Stability of $\mathrm{TiAl}_{3}$ Phases, Comput. Mater. Sci., 2018, 153, p 309-314

50. E. Illeková, P. Švec, and D. Janičkovič, Influence of the Processing on the Ordering Process in the Al-Ti Binary System with Composition Close to $\mathrm{Al}_{3} \mathrm{Ti}$, J. Phys: Conf. Ser., 2009, 144, p 012111

51. D. Sornadurai, B. Panigrahi, and V.S. Sastry, Ramani, Crystal Structure and X-ray Powder Diffraction Pattern of $\mathrm{Ti}_{2} \mathrm{ZrAI}$, Powder Diffr., 2000, 15(3), p 189-190

52. M. Premkumar, K.S. Prasad, and A.K. Singh, Structure and Stability of the B2 Phase in Ti-25Al-25Zr Alloy, Intermetallics, 2009, 17, p 142-145

53. A. Pathak and A.K. Singh, A First Principles Study of Structural and Mechanical Properties of $\mathrm{Ti}_{2} \mathrm{AlZr}$ Intermetallic, Intermetallics, 2015, 63, p 37-44

54. D. Sornadurai, V.S. Sastry, V.T. Paul, R. Flemming, F. Jose, R. Ramaseshan, and S. Dash, Microstructure, Crystal Structure and Mechanical Properties of the New Ternary Intermetallic Alloy Phase $\mathrm{Zr}_{2} \mathrm{TiAl}$, Intermetallics, 2012, 24, p 89-94

55. I.I. Kornilov, T.T. Nartova, and M.M. Savel'yeva, Phase equilibrium of alloys of the section $\mathrm{Ti}_{3} \mathrm{Al}-\mathrm{Zr}$ of the ternary system TiAl-Zr, Metallovedeniye Titana, I.I. Kornilov, Ed., Nauka, Moscow, 1964, p 53-57

56. X.J. Jiang, Y.K. Zhou, Z.H. Feng, C.Q. Xia, C.L. Tan, S.X. Liang, X.Y. Zhang, M.Z. Ma, and R.P. Liu, Influence of $\mathrm{Zr}$ Content on $\beta$-Phase Stability in $\alpha$-Type Ti-Al Alloys, Mat. Sci. Eng., 2015, A639, p 407-411

57. Y. Miyajima, K. Ishikawa, and K. Aoki, Hydrogen-Induced Amorphization in Ti-Al-Zr Compounds with $\mathrm{D}_{19}, \mathrm{~B} 2$ and FCC Structures, Mater. Trans., 2002, 43(5), p 1085-1088

58. M. Premkumar and A.K. Singh, Deformation Behavior of an Ordered B2 Phase in Ti-25Al-25Zr Alloy, Intermetallics, 2010, 18, p 199-201

59. G.N. Muradyan, S.K. Dolukhanyan, A.G. Aleksanyan, O.P. TerGalstyan, and N.L. Mnatsakanyan, Regularities and Mechanism of Formation of Aluminides in the $\mathrm{TiH}_{2}-\mathrm{ZrH}_{2}-\mathrm{Al}$ System, Russ. J. Phys. Chem. B, 2019, 13(1), p 86-95

60. C. Ravi, P. Vajeeston, S. Mathijaya, and R. Asokamani, Electronic Structure, Phase Stability, and Cohesive Properties of $\mathrm{Ti}_{2} \mathrm{XAl}(\mathrm{X}=\mathrm{Nb}, \mathrm{V}, \mathrm{Zr})$, Phys. Rev. B, 1999, 60(23), p $15683-15690$ 
61. C. Ravi and R. Asokamani, Site Preference of $\mathrm{Zr}$ in $\mathrm{Ti}_{3} \mathrm{Al}$ and Phase Stability of $\mathrm{Ti}_{2} \mathrm{ZrAl}$, Bull. Mater. Sci., 2003, 26(1), p 97-103

62. P. Modak, L.M. Ramaniah, and A.K. Singh, Structure of the B2 Phase in the Ti-25Al-25Zr Alloy: A Density Functional Study, $J$. Phys.: Condens. Matter, 2010, 22, p 345502

63. F. Fan, Y. Gu, G. Xu, H. Chang, and Y. Cui, Diffusion Research in BCC Ti-Al-Zr Ternary Alloys, J. Phase Equilib. Diffus., 2019, 40, p 686-696

64. I.I. Kornilov and N.G. Boriskina, Study of the phase structure of the alloys of the system $\mathrm{Ti}-\mathrm{Al}-\mathrm{Zr}$ along the $\mathrm{Ti}_{3} \mathrm{Al}-\mathrm{Zr}$ section, Metallovedeniye Titana, I.I. Kornilov, Ed., Nauka, Moscow, 1964, p 58-66

65. Y.L. Hao, D.S. Xu, Y.Y. Cui, R. Yang, and D. Li, The Site Occupancies of Alloying Elements in $\mathrm{TiAl}$ and $\mathrm{Ti}_{3} \mathrm{Al}$ Alloys, Acta Mater., 1999, 47(4), p 1129-1139

66. R. Yang, Y. Hao, Y. Song, and Z.-X. Guo, Site Occupancy of Alloying Additions in Titanium Aluminides and Its Application to Phase Equilibrium Evaluation, Z. Metallkd., 2000, 91(4), p 296-301

67. A. Prince, Alloy Phase Equilibria, Elsevier, Amsterdam, 1966

68. F. Stein, G. Sauthoff, and M. Palm, Phases and Phase Equilibria in the Fe-Al-Zr System, Z. Metallkd., 2004, 96(6), p 469-485

69. J.C. Schuster, J. Bauer, and J. Debuigne, Investigation of Phase Equilibria Related to Fusion Reactor Materials: I. The Ternary System Zr-AI-N, J. Nucl. Mater., 1983, 116(2-3), p 131-135

70. D. Tanda, T. Tanabe, R. Tamura, and S. Takeuchi, Synthesis of Ternary $\mathrm{L}_{0}$ Compounds of $\mathrm{Ti}-\mathrm{Al}-\mathrm{Zr}$ System and Their Mechanical Properties, Mat. Sci. Eng., 2004, A387-389, p 991-995

71. K. Kasahara, K. Hashimoto, H. Doi, and T. Tsujimoto, Crystal Structure and Hardness of TiAl Phase Containing Zirconium, Nippon Kinzoku Gakkaishi (Journal of the japan institute of metals), 1987, 51(4), p 278-284, in Japanese

72. Y.N. Pylaeva and M.A. Volkova, Study of the alloys of the ternary system Ti-Al-Zr, Metallovedeniye Titana, I.I. Kornilov, Ed., Nauka, Moscow, 1964, p 38-42

73. N.I. Shirokova and T.T. Nartova, Investigation of the phase equilibrium and properties of alloys of the titanium corner of the system Ti-Zr-Al, Titanovyye Splavy dlya Novoy Tekhniki, N.P. Sazhin, Ed., Nauka, Moscow, 1968, p 101-106

74. N.I. Shirokova, T.T. Nartova, and I.I. Kornilov, Investigation of the Phase Equilibrium and Properties of Ti-Zr-Al Alloys, Izvestia Akademii nauk SSSR. Metally, 1968, 1968(4), p 183-187 (in Russian)

75. T.T. Nartova and N.I. Shirokova, Phase equilibria and heat resistance of Ti-Zr-Al alloys, Izvestia Akademii nauk SSSR. Metally, 1970, 1970(3), p 194-198, in Russian

76. Y.N. Borisova and I.I. Shashenkova, Study of the properties of alloys of the sytems Ti-Zr and Ti-Zr-Al, Titanovyye Splavy dlya Novoy Tekhniki, N.P. Sazhin, Ed., Nauka, Moscow, 1970, p 202-207

77. D. $\mathrm{Xu}, \mathrm{W}$. Long, and $\mathrm{X}$. Zhou, Microstructure and Corrosion Resistance of $\mathrm{Al}_{3}(\mathrm{Zr}, \mathrm{Ti}) / \mathrm{Al}$ Composite Prepared by Powder Metallurgy, Adv. Compos. Lett., 2020, 29, p 1-9

78. D.L.Y. Li and X. Wan, On the Thermal Stability of Ti Alloys, Acta Metall. Sinica, 1984, 20(A), p 375-383

79. D.R. Sandlin and H.A. Klung, A Phase Study of a Selected Portion of the Ti-Al-Zr Ternary System Inclucing Lattice Parameter Determination for the Ti-Al Gamma Phase, Air University, Islamabad, 1961

80. T.B. Massalski, Binary Alloy Phase Diagrams, 2nd ed., ASM International, Metals Park, OH, 1990
81. N.I. Shirokova, T.T. Nartova, and I.I. Kornilov, Investigation of the Phase Equilibrium and Properties of Ti-Zr-Al Alloys, Russ. Metall. (Engl. Transl.), 1968, 1968(4), p 115-117

82. J.P. Gros, I. Ansara, and M. Allibert, Prediction of $\alpha / \beta$ equilibria in titanium-based alloys containing $\mathrm{Al}, \mathrm{Mo}, \mathrm{Zr}, \mathrm{Cr}$ (Part II), in 6th World Conference on Titanium, eds. by P. Lacombe, R. Tricot, G. Béranger (Les Editions de Physique, Cannes, France, 1988) Les Ulis Cedex, France, pp. 1559-1564

83. Z.X. Deng, D.P. Zhao, Y.Y. Huang, L.L. Chen, H. Zou, Y. Jiang, and $\mathrm{K}$. Chang, Ab Initio and CALPHAD-Type Thermodynamic Investigation of the Ti-Al-Zr System, J. Min. Metall., Sect. B, 2019, 55(3), p 427-437

84. H.K.C. Kumar, P. Wollants, and L. Delaey, Thermodynamic Assessment of the Ti-Zr System and Calculation of the Nb-Ti-Zr Phase Diagram, J. Alloys Compd., 1994, 202, p 121-127

85. S.I. Park, S.Z. Han, S.K. Choi, and H.M. Lee, Phase Equilibria of Al3(Ti, V, Zr) Intermetallic System, Scr. Mater., 1996, 34(11), p $1697-1704$

86. G. Ghosh, S. Vaynman, M. Asta, and M.E. Fine, Stability and Elastic Properties of L12-(Al, Cu)3(Ti, Zr) Phases: Ab Initio Calculations and Experiments, Intermetallics, 2007, 15, p 44-54

87. M.J. Blackburn, The Ordering Transformation in Titanium: Aluminum Alloys Containing up to 25 at pet Al, Trans. Metall. Soc. AIME, 1967, 239(8), p 1200-1208

88. J. Braun, M. Ellner, and B. Predel, Experimental Investigation of the Structure and Stability of the Phase TiAl, Z. Metallkd., 1995, 86(12), p 870-876

89. H. Mabuchi, T. Asai, and Y. Nakayama, Aluminide Coatings on TiAl Compound, Scr. Metall., 1989, 23, p 685-689

90. J.C.I. Schuster, Phases and Phase Relations in the Partial System $\mathrm{TiAl}_{3}$-TiAl, Z. Metallkd., 1990, 81(6), p 389-396

91. A.S. Raman, The Constitution of Some Alloy Series Related to $\mathrm{TiAl}_{3}$. II. Investigations in Some T-Al-Si and $\mathrm{T}^{4 \ldots 6}$-In Systems, Z. Metallkd., 1965, 56(1), p 44-52

92. R. Miida, One Dimensional Antiphase Domain Structures in the Aluminum-Rich Al-Ti Alloys, Jpn. J. Appl. Phys., 1986, 25(12), p $1815-1824$

93. F.J.J. van Loo and G.D. Rieck, Diffusion in the Titanium-Aluminium System-I. Interdiffusion Between Solid Al and Ti or TiAl Alloys, Acta Metall., 1973, 21(1), p 61-71

94. J. Braun and M. Ellner, Phase Equilibria Investigations on the Aluminium-Rich Part of the Binary System Ti-Al, Metall. Mater. Trans. A, 2001, 32A(5), p 1037-1047

95. M. Pötzschke and K. Schubert, Zum Aufbau einiger zu $T^{4}-B^{3}$ homologer und quasihomologer. Systeme II, Die Systeme Ti-Al, Zr-Al, Hf-Al, Mo-Al und einige ternäre Systeme, Z. Metallkd., 1962, 53(8), p 548-561 (in German)

96. H. Nowotny, H. Auer-Welsbach, J. Bruss, and A. Kohl, Ein Beitrag zur $\mathrm{Mn}_{5} \mathrm{Si}_{3}$-Struktur (D $88_{8}$-Typ). Monatsh, Chem. Verw. Teile Anderer Wiss. Chem. Mon., 1959, 90, p 15-23

97. J. Wang, W. Zheng, G. Xu, X. Zeng, and Y. Cui, Thermodynamic assessment of the $\mathrm{Ti}-\mathrm{Al}-\mathrm{Zr}$ system and atomic mobility of its bcc phase, CALPHAD, 2020, 70, p 101801

98. D.A. Abreu, A.A.A.P. Silva, J.C.P. Santos, D.F. Barros, C.S. Barros, N. Chaia, C.A. Nunes, and G.C. Coelho, Liquidus projection of the Al-Ti-Zr system, J. Alloys Compd., 2020, 849, p 156463

Publisher's Note Springer Nature remains neutral with regard to jurisdictional claims in published maps and institutional affiliations. 